\title{
Review \\ Biocatalytic C-C Bond Formation for One Carbon Resource Utilization
}

\author{
Qiaoyu Yang ${ }^{1,2,3}$, Xiaoxian Guo ${ }^{1,2}$, Yuwan Liu 1,2,* and Huifeng Jiang 1,2,* \\ 1 Key Laboratory of Systems Microbial Biotechnology, Tianjin Institute of Industrial Biotechnology, \\ Chinese Academy of Sciences, Tianjin 300308, China; yangqy@tib.cas.cn (Q.Y.); guoxx@tib.cas.cn (X.G.) \\ 2 National Technology Innovation Center of Synthetic Biology, Tianjin 300308, China \\ 3 University of Chinese Academy of Sciences, Beijing 100049, China \\ * Correspondence: liu_yw@tib.cas.cn (Y.L.); jiang_hf@tib.cas.cn (H.J.)
}

Citation: Yang, Q.; Guo, X.; Liu, Y.; Jiang, H. Biocatalytic C-C Bond Formation for One Carbon Resource Utilization. Int. J. Mol. Sci. 2021, 22, 1890. https://doi.org/10.3390/ ijms22041890

Academic Editor: Gianfranco Gilardi

Received: 22 December 2020

Accepted: 5 February 2021

Published: 14 February 2021

Publisher's Note: MDPI stays neutral with regard to jurisdictional claims in published maps and institutional affiliations.

Copyright: (c) 2021 by the authors. Licensee MDPI, Basel, Switzerland. This article is an open access article distributed under the terms and conditions of the Creative Commons Attribution (CC BY) license (https:// creativecommons.org/licenses/by/ $4.0 /)$.

\begin{abstract}
The carbon-carbon bond formation has always been one of the most important reactions in C1 resource utilization. Compared to traditional organic synthesis methods, biocatalytic C$\mathrm{C}$ bond formation offers a green and potent alternative for $\mathrm{C} 1$ transformation. In recent years, with the development of synthetic biology, more and more carboxylases and C-C ligases have been mined and designed for the $\mathrm{C} 1$ transformation in vitro and $\mathrm{C} 1$ assimilation in vivo. This article presents an overview of $\mathrm{C}-\mathrm{C}$ bond formation in biocatalytic $\mathrm{C} 1$ resource utilization is first provided. Sets of newly mined and designed carboxylases and ligases capable of catalyzing C-C bond formation for the transformation of $\mathrm{CO}_{2}$, formaldehyde, $\mathrm{CO}$, and formate are then reviewed, and their catalytic mechanisms are discussed. Finally, the current advances and the future perspectives for the development of catalysts for $\mathrm{C} 1$ resource utilization are provided.
\end{abstract}

Keywords: C1 resource utilization; carboxylases; C-C ligases; designed pathway

\section{Introduction}

It has been estimated that more than $35 \%$ of industrial chemicals will be produced by bio-manufacturing until 2030 [1]. C1 resources, including methane, methanol, formaldehyde, formic acid, and carbon dioxide, are ideal raw materials for bio-manufacturing, due to their low cost and easy availability. In nature, six $\mathrm{CO}_{2}$ fixation pathways have been identified in photoautotrophic and chemoautotrophic microorganisms [2]. In addition to Calvin-Benson-Bassham (CBB) cycle, there are three major pathways that operate in methanotrophs or methylotrophic yeast for assimilation of methane or methanol, which are first oxidized to formaldehyde, and then is assimilated via the ribulose monophosphate (RuMP) cycle, serine cycle, or xylulose monophosphate pathway (XuMP) [3]. Engineering natural $\mathrm{C} 1$ assimilation pathways to achieve the production of biofuels or industrial chemicals has always been a research hotspot in synthetic biology [4-16]. However, the biotransformation of $\mathrm{C} 1$ resources is restricted in the industry by low production efficiency, limited product types, and high production costs.

With the development of synthetic biology, more and more $\mathrm{C} 1$ utilization pathways have been exploited in recent years. These pathways can be broadly divided into two categories. One refers to $\mathrm{C} 1$ transformation in vitro. Carboxylases and $\mathrm{C}-\mathrm{C}$ ligases from naturally occurring $\mathrm{C} 1$ assimilation pathways are highly specialized, and thus, restricted their use for the $\mathrm{C} 1$ biotransformation in vitro. It has been shown that (de)carboxylases involved in the secondary metabolism are generally reversible and promiscuous [17], several C-C ligases, such as aldolases and thiamine diphosphate (ThDP)-dependent enzymes [18], can receive formaldehyde as a receptor. These newly mined (de)carboxylases and C-C ligases greatly expand the scope of $\mathrm{C} 1$ resource utilization in vitro. The other refers to $\mathrm{C} 1$ assimilation in vivo. Based on highly active carboxylases or designed C-C ligases, several artificial $\mathrm{C} 1$ assimilation pathways have been constructed, such as malyl-CoA-glycerate 
pathway (MCG) [19], crotonyl-CoA/ethylmalonyl-CoA/hydroxybutyryl-CoA cycle pathway $(\mathrm{CETCH})[20,21]$, formolase pathway (FLS) [22], and synthetic acetyl-CoA pathway (SACA) [23]. Compared to the natural $\mathrm{C} 1$ assimilation pathways, these artificial pathways have obvious advantages in catalytic efficiency, biomass yield, and driving force, and are expected to improve the efficiency of $\mathrm{C} 1$ resource utilization in the future.

The overall efficiency of $\mathrm{C} 1$ transformation in vitro and $\mathrm{C} 1$ assimilation in vivo is generally determined by the biochemical properties of carboxylases and C-C ligases. A better understanding of the catalytic mechanisms of these enzymes is necessary for mining or design more efficient carboxylases and C-C ligases. Herein, we mainly summarized carboxylases, and C-C ligases for formaldehyde, CO, and formic acid. Furthermore, C1 transformation in vitro and $\mathrm{C} 1$ assimilation in vivo based on newly mined or designed carboxylases and C-C ligases are highlighted. Finally, a summary about the current advances and the future perspectives of the $\mathrm{C} 1$ resource utilization are presented.

\section{Carboxylases for $\mathrm{CO}_{2}$ Biotransformation}

$\mathrm{CO}_{2}$ is a poor electrophile and usually exists as bicarbonate in an aqueous solution. Therefore, the carboxylation reaction often requires energy (adenosine triphosphate (ATP), nicotinamide adenine dinucleotide phosphate (NADPH), or ferredoxin) or the assistance of coenzymes (metal ion, ThDP, and prenylated flavin mononucleotide (prFMN), etc.) [24]. We divide carboxylases into seven categories: (1) Only divalent metal-dependent carboxylases, (2) ATP-dependent carboxylases, (3) redox equivalents-dependent carboxylases, (4) substrate-activated carboxylases, (5) ThDP-dependent carboxylases, (6) multi-enzyme complex constructed carboxylase, (7) prFMN-dependent carboxylases. Representative carboxylases are shown in Table 1.

Table 1. Representative carboxylases for $\mathrm{CO}_{2}$ fixation.

\begin{tabular}{cccc}
\hline Aliphatic Substrates & Enzyme and Category & Pathway \\
\hline D-ribulose 1,5-bisphosphate & 3-phosphoglycerate & $\begin{array}{c}\text { Rubisco } \\
\begin{array}{c}\text { EC 4.1.1.39 } \\
\text { Only divalent } \\
\text { metal-dependent } \\
\text { carboxylase }\end{array}\end{array}$ & $\begin{array}{c}\text { Calvin-Benson-Bassham } \\
\text { (CBB) cycle }\end{array}$ \\
\hline
\end{tabular}<smiles>CC(=O)C(=O)O</smiles>

pyruvate<smiles>O=C(O)CC(=O)C(=O)O</smiles>

oxaloacetate
$\mathrm{PC}$

EC 6.4.1.1

ATP-dependent carboxylase<smiles>CC(=O)[Se]O</smiles>

acetyl-CoA<smiles>O=C(O)CC(=O)[Se]O</smiles>

malonyl-CoA
ACC

EC 6.4.1.2

ATP-dependent carboxylase 3-hydroxypropionate cycle (HP) and

3-HP/4-hydroxybutyrate cycle $(\mathrm{HB})$<smiles>CCC(=O)S(=O)OCCCCC(=O)O</smiles>

propionyl-CoA
PCC

EC 6.4.1.3

ATP-dependent carboxylase
3-HP

and 3-HP/4-HB

(S)-methylmalonyl-CoA 
Table 1. Cont.

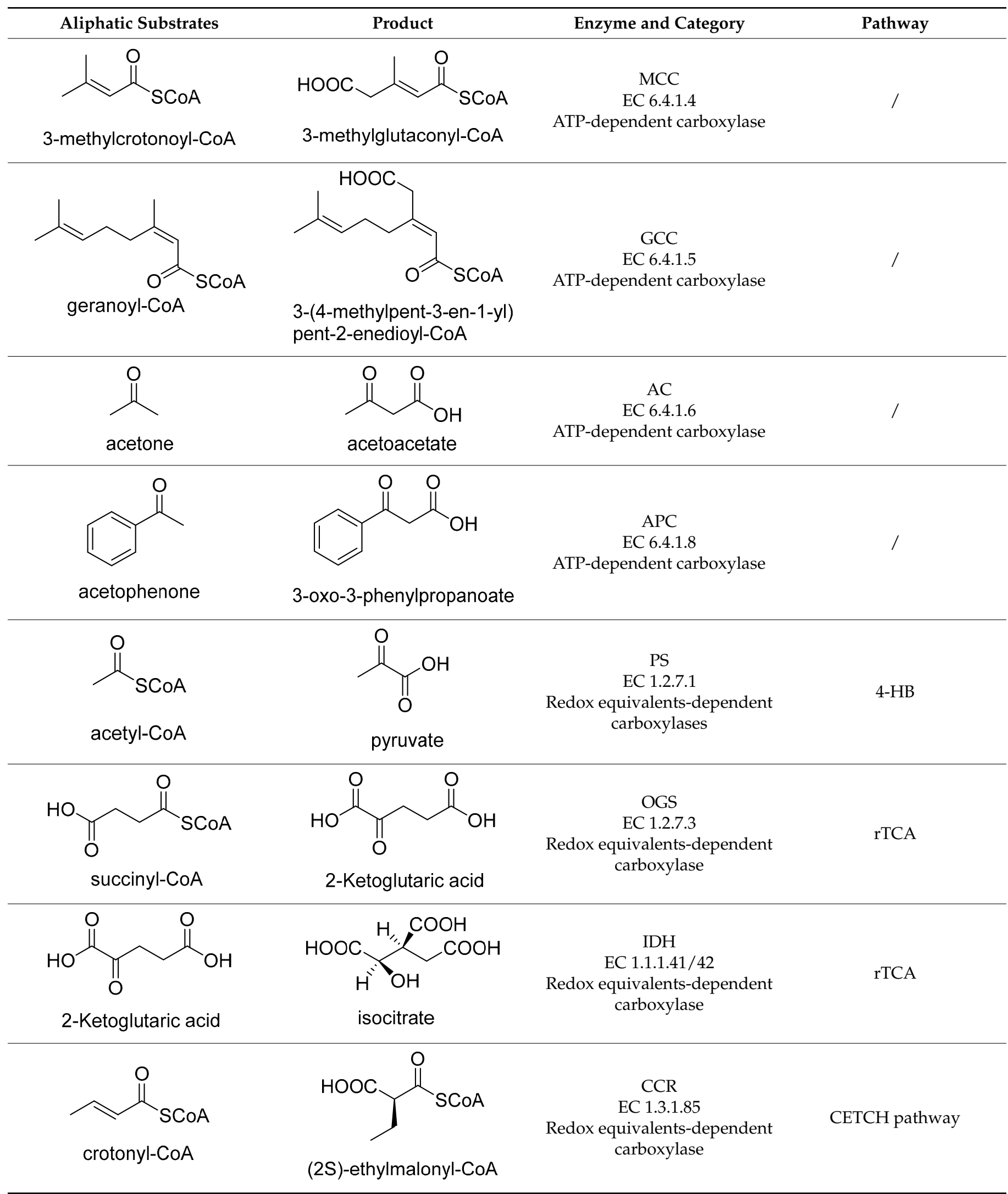


Table 1. Cont.

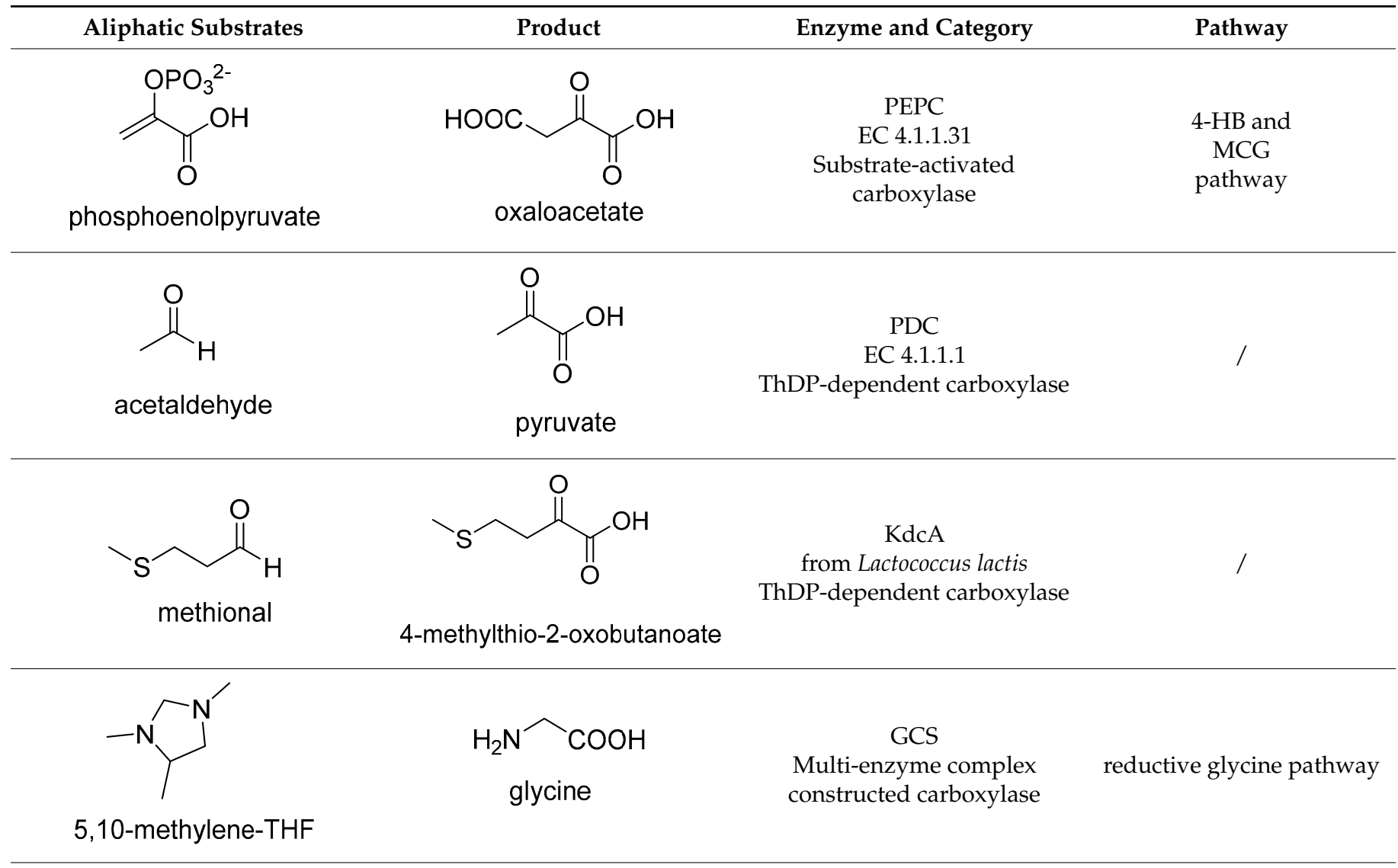<smiles>C=Cc1ccccc1</smiles>

styrene<smiles>O=C(O)/C=C/c1ccccc1</smiles>

cinnamic acid
Ferulic acid decarboxylase (FDC1) prFMN-dependent carboxylase<smiles>c1ccccc1</smiles>
benzene

$\mathrm{OH}$<smiles>Oc1ccccc1O</smiles>

catechol<smiles>c1cc[nH]c1</smiles>

pyrrole<smiles>O=C(O)c1ccccc1</smiles>

benzoic acid

\section{Benzene carboxylase prFMN-dependent carboxylase}

3,4-dihydroxybenzoic acid

decarboxylase from E. cloacae (EcAroY) prFMN-dependent carboxylase

3,4-dihydroxybenzoic acid

Pyrrole-2-carboxylic acid decarboxylase prFMN-dependent carboxylase

\subsection{Only Divalent Metal-Dependent Carboxylases}

The CBB cycle is the most important $\mathrm{CO}_{2}$ assimilation pathway on earth, and is used by most photosynthetic organisms (such as plants, algae, cyanobacteria, and most aerobic or facultative aerobic Eubacteria) to assimilate $\mathrm{CO}_{2}$ into biomass [25]. D-ribulose- 
1, 5-bisphosphate carboxylase/oxygenase (Rubisco, EC 4.1.1.39) is the key carboxylase, which converts $\mathrm{CO}_{2}$ and ribulose-1, 5-bisphosphate to 3-phosphoglycerate [26]. The catalytic process of Rubisco is that the enolate form of ribulose-1, 5-bisphosphate launches a nucleophilic attack onto $\mathrm{CO}_{2}$ assisted by an essential $\mathrm{Mg}^{2+}$, to produce a labile C6- $\beta$ ketoacid intermediate, which is hydrolytically cleaved into 3-phosphoglycerate (Figure 1). RubisCO shows two major flaws. One is the low catalytic activity, which has an average turnover number of $5 \mathrm{~s}^{-1}[27,28]$. The other is a side reaction with $\mathrm{O}_{2}$, causing carbon loss.

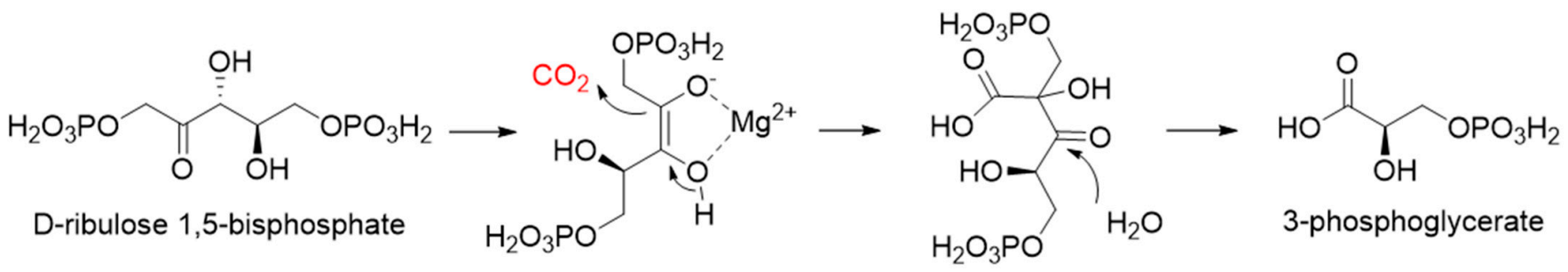

Figure 1. The catalytic mechanism of Rubisco [26].

Due to the high complexity of the catalytic mechanism and the unique position of RubisCO in biosynthesis, it is unlikely that this enzyme can accept non-natural substrate analogs to produce carboxylic acids. In addition to engineering cyanobacteria or microalgae to produce various biofuels and industrial chemicals, the reconstruction of the CBB cycle based on RubisCO in industrial microbial model strains (Escherichia coli, etc.) has made a series of progress [29-31]. By co-expressing Rubisco, phosphoribulokinase, and formate dehydrogenase, Shmuel Gleizer et al. engineered E. coli to produce all its biomass carbon from $\mathrm{CO}_{2}$ via the $\mathrm{CBB}$ cycle [30]. By adding eight heterologous genes and deleting three native genes, Thomas Gassler et al. engineered the peroxisomal methanol-assimilation pathway of $P$. pastoris into a $\mathrm{CO}_{2}$-fixation pathway resembling the $\mathrm{CBB}$ cycle [31], the resulting strain can grow continuously with $\mathrm{CO}_{2}$ as a sole carbon source at a $\mu_{\max }$ of $0.008 \mathrm{~h}^{-1}$.

\subsection{ATP-Dependent Carboxylases}

Biotin-dependent carboxylases include pyruvate carboxylase (PC, EC 6.4.1.1), acetylCoA carboxylase (ACC, EC 6.4.1.2), propionyl-CoA carboxylase (PCC, EC 6.4.1.3), 3methylcrotonoyl-CoA carboxylase (MCC, EC 6.4.1.4), and geranoyl-CoA carboxylase (GCC, EC 6.4.1.5). They are widely distributed in nature and can be found in archaea, bacteria, algae, fungi, plants, and animals [32]. The catalytic process of biotin-dependent carboxylases can be divided into two steps (Figure 2). First, the biotin carboxylase (BC) domain catalyzes the ATP-dependent carboxylation of the $\mathrm{N}^{\prime}$ atom of the biotin cofactor, using bicarbonate as the $\mathrm{CO}_{2}$ donor. Second, the carboxyltransferase (CT) domain transfers the $\mathrm{CO}_{2}$ from carboxy-biotin to the substrates [33-35]. The site for carboxylation is on the $\alpha$-carbon of saturated substrates (pyruvate, acetyl-CoA, and propionyl-CoA) or the $\gamma$-carbon of $\alpha$, $\beta$-unsaturated substrates (3-methylcrotonyl-CoA, geranyl-CoA). Acetyl-CoA carboxylase and propionyl-CoA carboxylase are two carboxylases of 3-hydroxypropionate/malyl-CoA cycle and 3-hydroxypropionate/4-hydroxybutyrate cycle [36,37].

Acetone carboxylases (AC, EC 6.4.1.6) are soluble cytoplasmic enzymes, and can be found in many species of aerobic, anaerobic phototrophic bacteria, and even microaerobic gastric human pathogenic species Helicobacter pylori. They catalyze the carboxylation of acetone to form acetoacetate at the expense of ATP [38]. There are two different types of acetone carboxylases. One requires 2 ATP equivalents as an energy supply for the carboxylation reaction, while another requires 4 ATP equivalents. The main difference in catalytic mechanism lies in the processes of substrate activation. The catalytic mechanism proposed for acetone carboxylase of Xanthobacter/Rhodobacter is that one ATP is sequentially hydrolyzed to ADP and AMP to activate acetone and bicarbonate, respectively. While the catalytic mechanism of acetone carboxylase from Aromatoleum is that 2 ATP are hydrolyzed 
to 2 AMP to active two substrates [39]. Acetoacetate can be activated by a CoA ligase to form acetoacetyl-CoA, which is cleaved to form 2 acetyl-CoA by thiolase. Therefore, a new pathway from isopropanol and $\mathrm{CO}_{2}$ to acetyl-CoA can be constructed. Acetophenone carboxylase (APC, EC 6.4.1.8) catalyzes the carboxylation of acetophenone to benzoylacetate [40]. Different from the above two activation processes of acetone carboxylases, acetophenone and bicarbonate are all activated by hydrolyzing ATP to ADP.

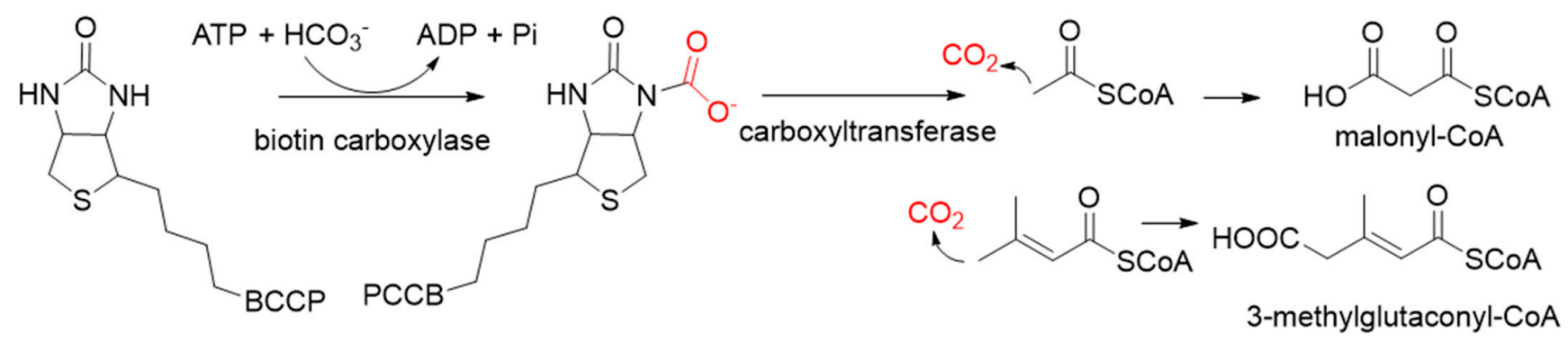

Figure 2. The catalytic process of biotin-dependent carboxylases [33-35].

\subsection{Redox Equivalents-Dependent Carboxylases}

Pyruvate synthase (PS, EC 1.2.7.1) and 2-oxoglutarate synthase (OGS, EC 1.2.7.3) are a class of enzymes sharing a similar catalytic mechanism [41,42]. They belong to strictly anaerobic enzymes and show low catalytic activity. Acetyl-CoA can be reductively carboxylated by pyruvate synthase at the expense of two equivalents of ferredoxin to generate pyruvate. Similarly, succinyl-CoA can be converted to 2-oxoglutarate by 2-oxoglutarate synthase [43]. Different from the above two enzymes, isocitrate dehydrogenase (IDH, EC 1.1.1.41/42) converts 2-oxoglutarate to isocitrate at the expense of NAD(P)H [44]. The carboxylation process of isocitrate dehydrogenase is assumed to proceed via the enolate intermediate of 2-oxoglutarate, which is formed with the assistance of divalent metal ions $\mathrm{Mg}^{2+}$ or $\mathrm{Mn}^{2+}$. After the addition of $\mathrm{CO}_{2}$, the unstable keto-tricarboxylic acid intermediate is immediately reduced by $\mathrm{NAD}(\mathrm{P}) \mathrm{H}$ to yield stable isocitrate (Figure 3A). 2-oxoglutarate synthase and isocitrate dehydrogenase are carboxylases of the reductive tricarboxylic acid (rTCA) cycle.

A

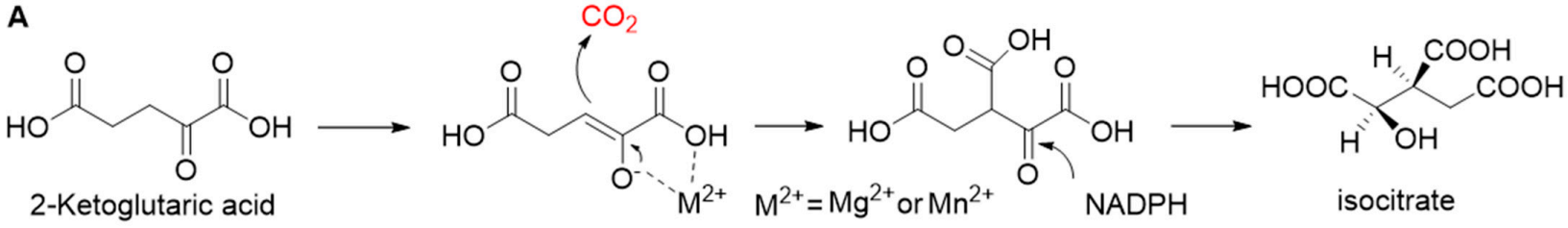

B<smiles>C/C=C/C(=O)S(=O)(=O)OC(=O)OC(=O)OC</smiles>
NADPH<smiles>CC=CC(=O)SOCC</smiles><smiles>CCC(C(=O)[O-])=C([O-])S(=O)(=O)O</smiles><smiles>CC</smiles><smiles>CC[C@H](C(=O)O)C(=O)[Se]O</smiles>

(2S)-ethylmalonyl-CoA

Figure 3. The catalytic mechanism of isocitrate dehydrogenase and crotonyl-CoA carboxylase/reductase. (A) The catalytic mechanism of isocitrate dehydrogenase [44]. (B) The catalytic mechanism of crotonyl-CoA carboxylase/reductase [45].

Enoyl-CoA carboxylases/reductases (ECRs) are a class of carboxylases that exist in secondary metabolism, as well as in central carbon metabolism of $\alpha$-proteobacteria and Streptomycetes [45]. The best-studied ECR is crotonyl-CoA carboxylase/reductase (CCR, EC 1.3.1.85) that catalyzes NADPH-dependent reductive carboxylation of crotonylCoA into (2S)-ethylmalonyl-CoA. The mechanism of CCR is assumed to proceed via nucleophilic hydride attack at $\beta$-carbon of the enoyl-CoA ester; the forming enolate is 
trapped by $\mathrm{CO}_{2}$ to generate (2S)-ethylmalonyl-CoA (Figure 3B). Recently, combining experimental biochemistry, protein crystallography, and advanced computer simulations, Gabriele M. M. Stoffel et al. determined the $\mathrm{CO}_{2}$-binding residues at the active site of crotonyl-CoA carboxylase/reductase from Kitasatospora setae [46]. Propionyl-CoA synthase from Erythrobacter sp. NAP1, as well as an acrylyl-CoA reductase from Nitrosopumilus maritimus, have almost no carboxylation activity. Based on the determined $\mathrm{CO}_{2}$-binding residues, they used rational design to engineer two enzymes into carboxylases by increasing interactions of the proteins with $\mathrm{CO}_{2}$ and suppressing diffusion of water to the active site [47].

Relative to Rubisco, CCR is oxygen-insensitive, does not react with $\mathrm{O}_{2}$, requires only the $\mathrm{NADPH}$, and catalyzes $\mathrm{CO}_{2}$ fixation with higher efficiency $\left(\mathrm{K}_{\text {cat }} / \mathrm{K}_{\mathrm{m}}=1642.6 \mathrm{~s}^{-1} \mathrm{mM}^{-1}\right)[48,49]$. All of these characteristics make CCR a good candidate enzyme for the fixation of $\mathrm{CO}_{2}$. Based on CCR, Tobias J. Erb research group constructed a crotonyl-CoA/ethylmalonylCoA/hydroxybutyryl-CoA (CETCH) cycle in vitro [21], which consists of 17 enzymes and can convert $\mathrm{CO}_{2}$ into organic molecules at a rate of 5 nanomoles of $\mathrm{CO}_{2}$ per minute per milligram of protein (Figure 4). Recently, they successfully encapsulated thylakoids isolated from the spinach plant along with all enzymes of the CETCH pathway within water-in-oil droplets [20]. The encapsulated system could use light energy to produce glycolate from $\mathrm{CO}_{2}$, while also phosphorylating ADP to ATP.

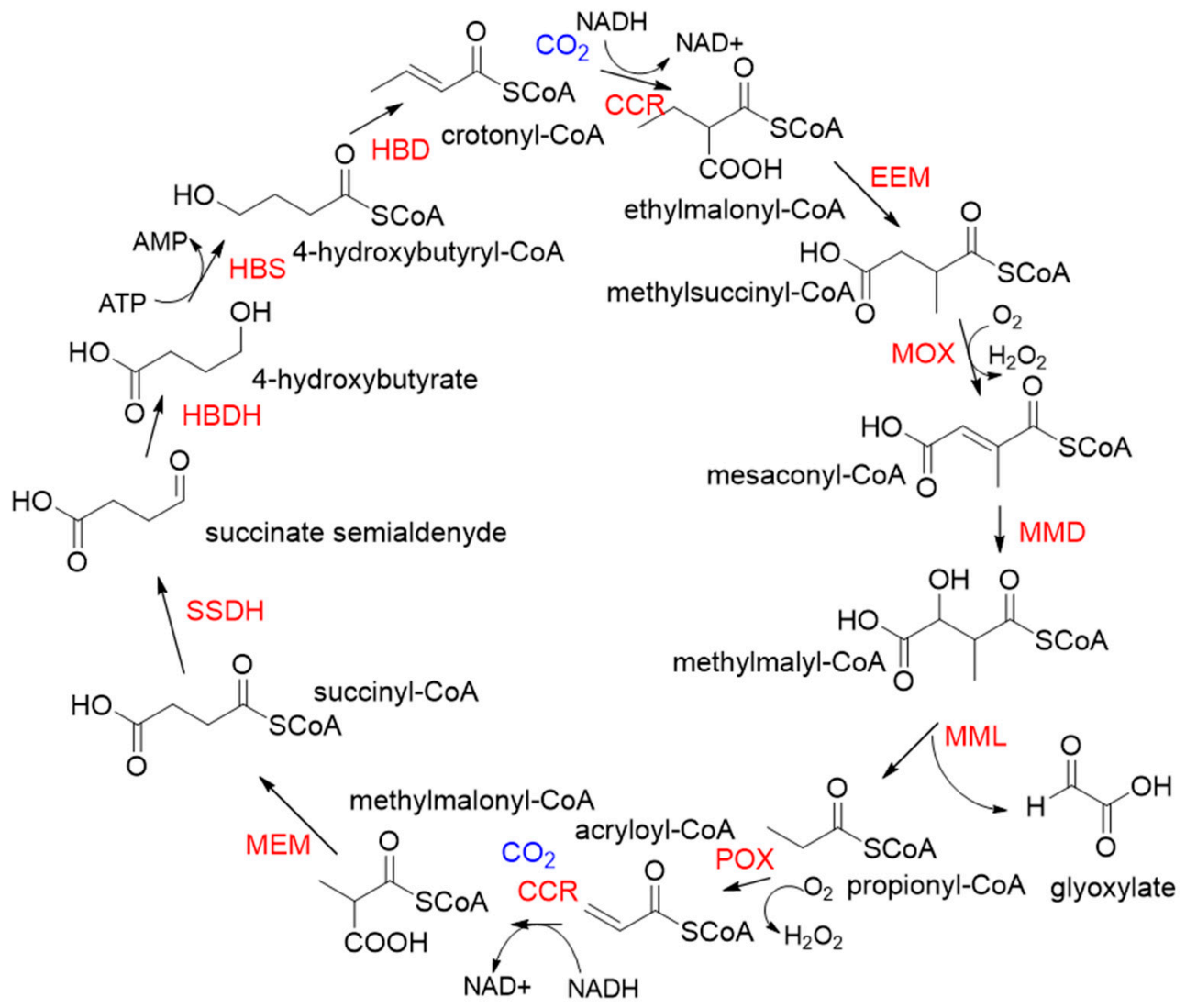

Figure 4. The crotonyl-CoA/ethylmalonyl-CoA/hydroxybutyryl-CoA cycle pathway (CETCH pathway) [21]. CCR, crotonyl-CoA carboxylase/reductase; EEM, ethylmalonyl-CoA epimerase, and mutase; MOX, methylsuccinyl-CoA oxidase; MMD, methylmalyl-CoA dehydratase; MML, methylmalyl-CoA lyase; POX, propionyl-CoA oxidase; MEM, methylmalonylCoA epimerase, and mutase; $\mathrm{SSDH}$, succinate semialdehyde dehydrogenase; HBDH, 4-hydroxybutyrate dehydrogenase; HBS, 4-hydroxybutyryl-CoA synthetase; HBD, 4-hydroxybutyryl-CoA dehydratase. 


\subsection{Substrate-Activated Carboxylases}

Phosphoenolpyruvate (PEP) carboxylase (PEPC, EC 4.1.1.31) catalyzes the irreversible carboxylation of PEP to form oxaloacetate (OAA) using $\mathrm{Mg}^{2+}$ or $\mathrm{Mn}^{2+}$ as a cofactor [50]. This kind of enzyme is present in most photosynthetic organisms [51]. PEPC is used to replenish intermediates of the TCA cycle for amino acid biosynthesis, or to shuttle $\mathrm{CO}_{2}$ between the mesophyll and bundle sheath cells in $\mathrm{C} 4$ plants. The catalytic mechanism of PEPC has been well studied (Figure 5). First, bicarbonate act as a nucleophile to attack phosphate groups in PEP, yielding carboxyphosphate and enolates of pyruvate, which is stabilized by metal ions $\mathrm{Mn}^{2+}$. Next, carboxyphosphate decomposes into inorganic phosphate and $\mathrm{CO}_{2}$, which is attacked by enolates of pyruvate to form OAA [52].

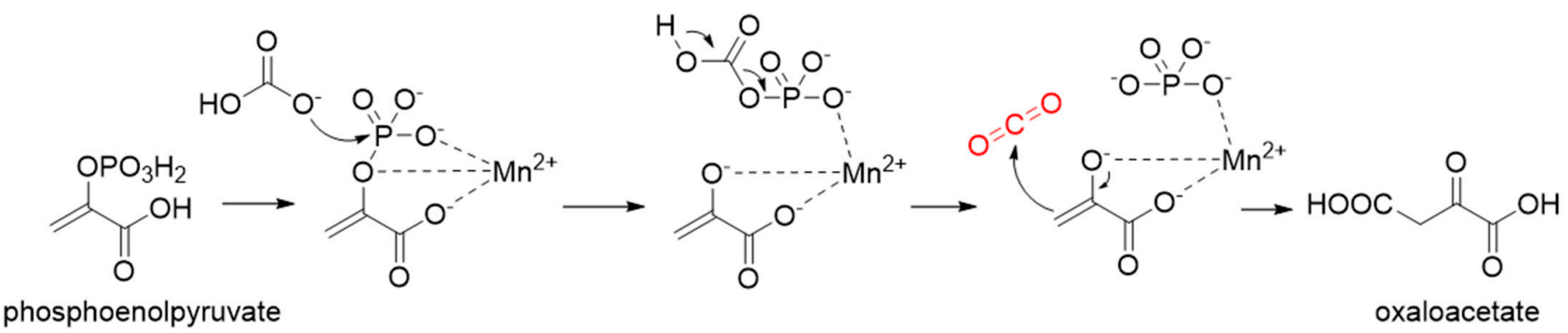

Figure 5. The catalytic mechanism of phosphoenolpyruvate carboxylase [52].

PEPC is known to be one of the most active carboxylases $\left(\mathrm{K}_{\mathrm{cat}} / \mathrm{K}_{\mathrm{m}}=23,792 \mathrm{~s}^{-1} \mathrm{mM}^{-1}\right)$ [53]. Based on PEPC, Hong Yu et al. constructed a synthetic malyl-CoA-glycerate (MCG) pathway [19], which is capable of converting one $\mathrm{C} 3$ sugar to two acetyl-CoA via fixation of one $\mathrm{CO}_{2}$ equivalent, or assimilating glyoxylate, a photorespiration intermediate, to produce acetyl-CoA without carbon loss (Figure 6). Coupling the MCG pathway with the $\mathrm{CBB}$ cycle, photosynthetic organisms utilize only 5.5 ATP and 1.5 Rubisco turnovers to produce one acetyl-CoA from $\mathrm{CO}_{2}$ equivalents, while the native pathway requires 7 ATP and 3 Rubisco turnovers. When transferring the MCG pathway into a photosynthetic organism Synechococcus elongates PCC7942, the intracellular acetyl-CoA level increased, and bicarbonate assimilation was improved by roughly 2 -fold.

\subsection{ThDP-Dependent Carboxylases}

Pyruvate decarboxylase (PDC, EC 4.1.1.1) is a key enzyme of carbon metabolism at the branching point between aerobic respiration and anaerobic alcoholic fermentation, and can be found in some bacteria, yeasts, and plants [54]. PDC catalyzes the decarboxylation of pyruvate by using ThDP and $\mathrm{Mg}^{2+}$ as cofactors (Figure 7). This enzyme has been successfully applied to yield pyruvic acid through the reverse carboxylation reaction. To favor the carboxylation, high $\mathrm{pH}$ and high bicarbonate concentration are needed [55]. In addition to using a high concentration of bicarbonate solution as a $\mathrm{CO}_{2}$ source, elevated $\mathrm{CO}_{2}$ pressure is also an effective way to drive the direction of carboxylation. Combining branched-chain $\alpha$-keto acid decarboxylase (KdcA) from Lactococcus lactis with transaminase or amino acid dehydrogenase, Julia Martin et al. achieved the synthesis of L-methionine from the abundant industrial intermediate methional under a 2 bar $\mathrm{CO}_{2}$ atmosphere [56]. 


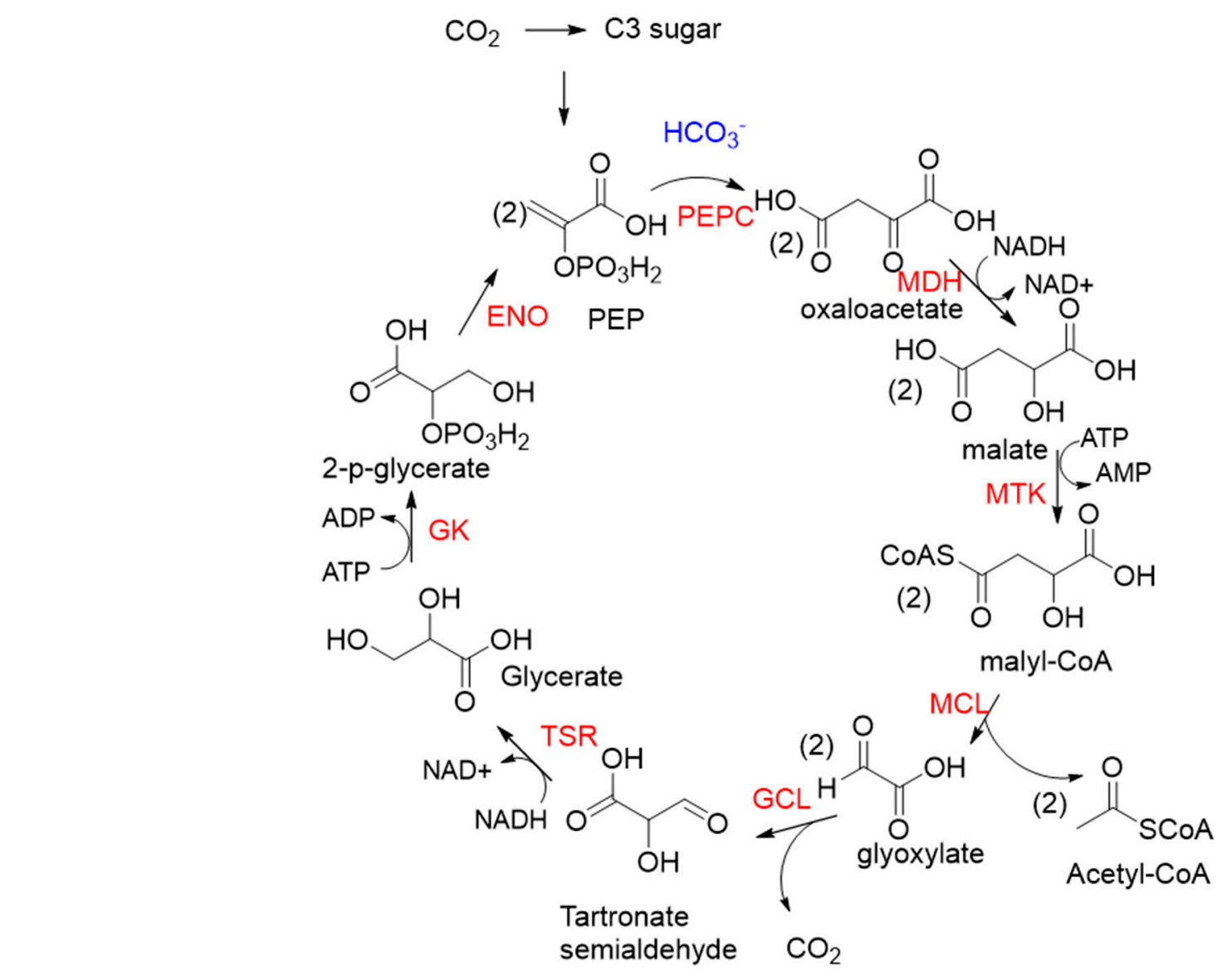<smiles>CC=O</smiles>

acetaldehyde
Figure 6. The synthetic malyl-CoA-glycerate (MCG) pathway [19]. PEPC, PEP carboxylase; MDH, malate dehydrogenase; MTK, malate thiokinase; MCL, malyl-CoA lyase; GCL, glyoxylate carboligase; TSR, tartronate semialdehyde reductase; GK, glycerate kinase; ENO, enolase.

$\mathrm{R}=\left(\mathrm{CH}_{2}\right)_{2} \mathrm{OPP}$<smiles></smiles><smiles>CC(C)(C)C1(C)CCCCC1</smiles>

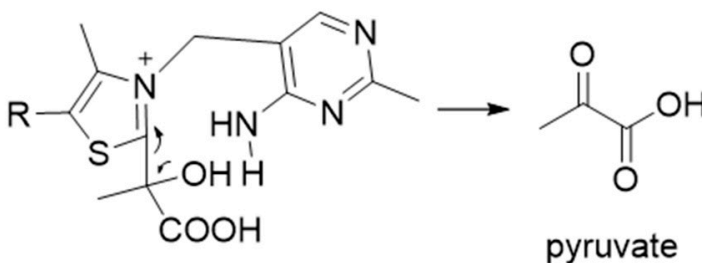

Figure 7. The catalytic mechanism of pyruvate decarboxylase $[54,55]$.

\subsection{Multi-Enzyme Complex Constructed Carboxylase}

The glycine cleavage system (GCS) is common among many organisms because of its involvement in glycine and serine catabolism [57]. The GCS converts glycine to $\mathrm{CO}_{2}$, $\mathrm{NH}_{4}{ }^{+}$, and methylene-THF. GCS is composed of four proteins, a carrier protein, and three enzymes. They are lipoic acid-containing protein $(\mathrm{GcvH})$, glycine dehydrogenase (GcvP), aminomethyltransferase (GcvT), and lipoamide dehydrogenase (Lpd), respectively. The glycine cleavage process can be divided into three steps. The first step is the decarboxylation of glycine by the glycine dehydrogenase. The decarboxylated moiety is then further degraded by the aminomethyl transferase with the aid of tetrahydrofolate. The last step is the reoxidation of the two sulfhydryl groups to form lipoic acid-generating NADH by dihydrolipomide dehydrogenase. Two sulfhydryl groups or lipoate attached to the lipoic acid-containing protein act as intermediate shuttles.

Now, GCS is confirmed to be reversible (rGCS) and can condense the C1 moiety of methylene-THF with $\mathrm{CO}_{2}$ and ammonia to produce glycine [58], which shows great 
application potential for reductive glycine pathway (RGP). Arren Bar-Even's research group has made a series of encouraging progress [59-61]. Especially, they redesigned the central carbon metabolism of the model bacterium $E$. coli for growth on one-carbon compounds (formate and methanol) using the RGP [61] (Figure 8). Recently, Irene Sánchez-Andrea et al. demonstrated that sulfate-reducing bacterium Desulfovibrio desulfuricans (strain G11) could grow autotrophically via the RGP using hydrogen and sulfate as energy substrates [62]. This work first demonstrates that autotrophic microbial growth can be fully supported by RGP, which is a highly ATP-efficient $\mathrm{CO}_{2}$ fixation pathway.

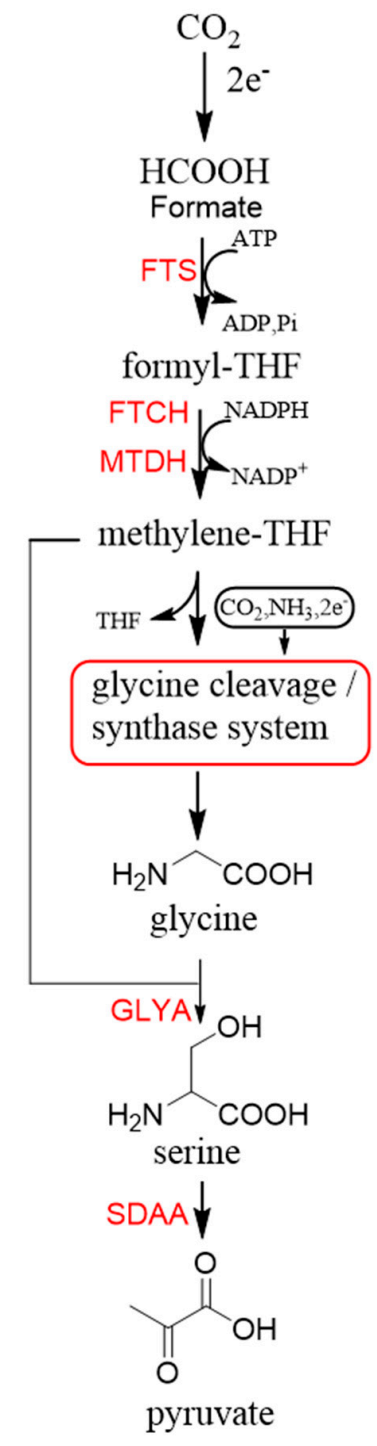

Figure 8. The reductive glycine pathway (RGP) [61]. FTS, formyl-THF synthase; FTCH, formyl-THF cyclohydrolase; MTDH, methylene-THF dehydrogenase; GLYA, L-serine hydroxymethyltransferase; SDAA, L-serine dehydratase.

\section{7. prFMN-Dependent Carboxylases}

prFMN-dependent decarboxylases catalyze the non-oxidative reversible decarboxylation of aromatic substrates, and play a pivotal role in bacterial ubiquinone (coenzyme Q) biosynthesis and microbial biodegradation of aromatic compounds $[63,64]$. The prFMN cofactor is provided by an associated prenyltransferase (UbiX), which extends the isoalloxazine FMN ring system through prenylation with a fourth non-aromatic ring. The catalytically active iminium species of the cofactor ( prFMN $^{\text {iminium }}$ ) is obtained by oxidizing the reduced prFMN with $\mathrm{O}_{2}$. There are two different catalytic reaction mechanisms for 
the prFMN-assisted (de)carboxylation reaction. For $\alpha, \beta$-unsaturated carboxylic acids, the reaction proceeds through the intermolecular 1,3-dipolar cycloaddition step. While for protocatechuic acid-type substrates, the electrophilic character of the iminium ion of prFMNiminium enables reversible (de)carboxylation via a mono-covalently bound quinoidcofactor intermediate. prFMN-dependent decarboxylases encompass a wide range of substrates [17], including non-aromatic $\alpha, \beta$-unsaturated (acrylic) acid derivatives, catechol, and 4-hydroxybenzoic acid derivatives, polycyclic aromatic hydrocarbons (PAHs), and heterocyclic substrates. Recently, combining ferulic acid decarboxylase (FDC, prFMNdependent) with carboxylic acid reductase (CAR), alcohol dehydrogenase (ADH), or imine reductase (IRED), Godwin A. Aleku et al. designed cascade reactions to enable efficient functionalization of terminal alkenes to the corresponding aldehyde, alcohol, amide or amine derivatives through ambient $\mathrm{CO}_{2}$ fixation [65].

\section{C-C Ligases for Formaldehyde Biotransformation}

Formaldehyde is a cytotoxic compound and a central metabolic intermediate in methylotrophs [66]. In addition to the naturally occurring formaldehyde condensing enzymes, such as dihydroxyacetone synthase (DAS), 3-hexulose-6-phosphate synthase (HPS), and serine hydroxymethyltransferase (SHMT), several promiscuous enzymes display catalytic activity towards formaldehyde. Based on the catalytic mechanism, those enzymes can be divided into 4 categories (Figure 9). Class I aldolases activate the donor substrate with a lysine residue. Class II aldolases use a metal cofactor to facilitate the activation of donor substrate to an enolate. The third class is hydroxymethyl pyridoxal $5^{\prime}$-phosphate (PLP) dependent enzymes. The PLP coenzyme activates the donor substrate to form a quinoide-aldimine intermediate. The last is ThDP-dependent enzymes. The ThDP coenzyme activates the donor substrate to form an enamine/carbanion intermediate. For the first three classes of enzymes, formaldehyde cannot act as a donor substrate because it is not enolizable. For ThDP-dependent enzymes, formaldehyde can act either as a donor or an acceptor. C-C ligases using formaldehyde as a donor or acceptor were summarized in Table 2. Furthermore, the formaldehyde assimilation pathways published in recent years are highlighted.
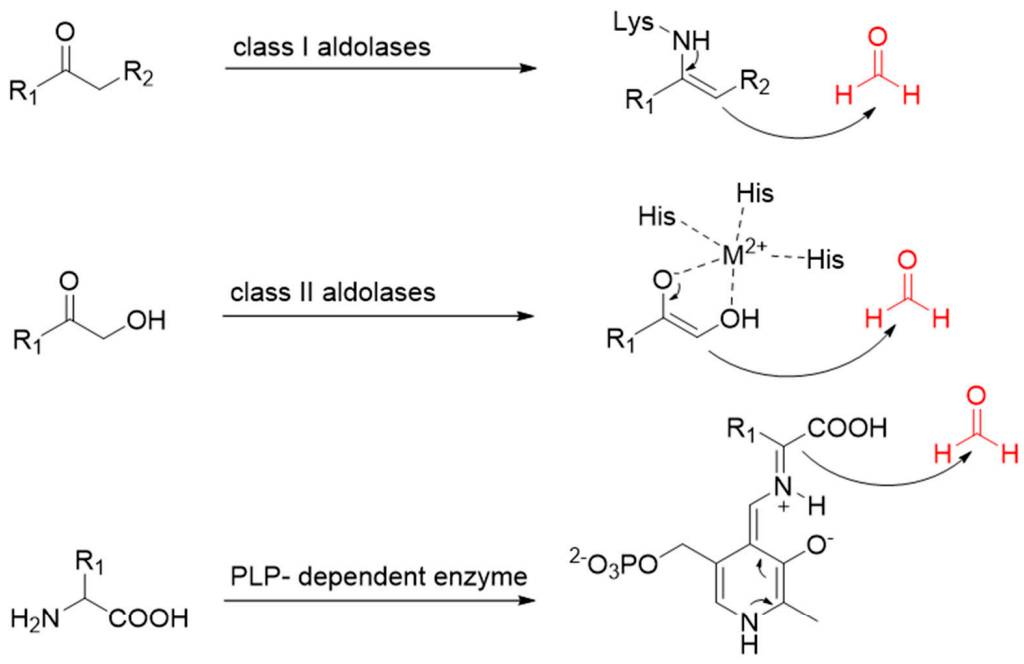<smiles>[R]C=O</smiles>
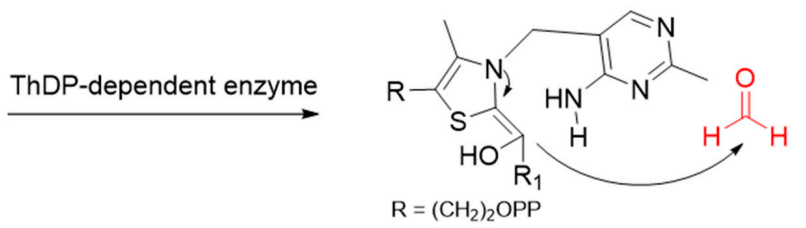

Figure 9. Four types of C-C Ligases for formaldehyde biotransformation [18]. 
Table 2. Summary of C-C Ligases with formaldehyde as a donor or acceptor.<smiles>CC(=O)C(=O)O</smiles>

pyruvate<smiles>O=C(O)C(=O)CCO</smiles>

4-hydroxy-2-oxobutyric acid
Enzyme and Category

Pathway

4-hydroxy-2-oxoglutarate aldolase (EC

$$
\text { 4.1.3.16) }
$$

class I aldolase

D-Fructose-1,6-bisphosphate (FBP)

aldolases (FruA, EC 4.1.2.13), and

Tagatose 1,6-diphosphate aldolase (Tag

A, EC 4.1.2.40):

class I aldolase dihydroxyacetone phosphate<smiles></smiles>

(S)-erythrulose phosphate<smiles>O=C(CO)[C@@H](O)CO</smiles>

(R)-Erythrulose
D-Fructose-6-phosphate aldolase (FSA) class I aldolase

dihydroxyacetone<smiles>CC(=O)CO</smiles>

hydroxyacetone<smiles>CC(=O)[C@@H](O)CO</smiles>

D-Fructose-6-phosphate aldolase (FSA) class I aldolase

(S)-3,4-dihydroxy-2-butanone<smiles>O=CCO</smiles>

glycolaldehyde<smiles>O=CC(O)CO</smiles>

(S)-glyceraldehyde
D-Fructose-6-phosphate aldolase (FSA) class I aldolase

\section{/}

\begin{tabular}{|c|c|c|c|}
\hline$\overbrace{\mathrm{O}}^{\overbrace{\mathrm{OH}}^{\mathrm{OH}}} \overbrace{\mathrm{OPO}_{3}}$ & $\underbrace{\mathrm{OH}}_{\substack{\mathrm{O} \\
\mathrm{OH}}} \mathrm{OPO}_{3}^{2}$ & $\begin{array}{c}\text { Hexulose phosphate synthase (HPS, EC } \\
4.1 .2 .43 \text { ) } \\
\text { class II aldolase }\end{array}$ & RuMP \\
\hline D-ribulose 5-phosphate & 3-hexulose-6-phosphate & & \\
\hline pyruvate & 4-hydroxy-2-oxobutyric acid & $\begin{array}{c}\text { 2-keto-3-deoxy-L-rhamnonate aldolase } \\
\text { (YfaU, EC 4.1.2.53) } \\
\text { class II aldolase }\end{array}$ & $\begin{array}{c}\text { the homoserine } \\
\text { cycle }\end{array}$ \\
\hline $\mathrm{H}_{2} \mathrm{~N}_{\text {glycine }} \mathrm{COOH}$ & $\mathrm{H}_{\text {Serine }} \mathrm{COOH}$ & $\begin{array}{c}\text { Serine hydroxymethyltransferase } \\
\text { (SHMT, EC 2.1.2.1) } \\
\text { PLP-dependent aldolase }\end{array}$ & $\begin{array}{c}\text { serine cycle and } \\
\text { RGP }\end{array}$ \\
\hline
\end{tabular}


Table 2. Cont.

\begin{tabular}{|c|c|c|c|}
\hline Substrates & Product & Enzyme and Category & Pathway \\
\hline$\overbrace{\mathrm{H}}^{\mathrm{R}} \overbrace{\mathrm{COOH}}$ & $\mathrm{H}_{2} \mathrm{~N}^{-}$ & $\begin{array}{c}\text { MSHMT for D-alanine. } \alpha \text {-Methylserine } \\
\text { aldolase for } \\
\text { D-alanine and D-butanine }\end{array}$ & / \\
\hline $\mathrm{R}=\mathrm{CH}_{3}, \mathrm{CH}_{2} \mathrm{CH}_{3}$ & $\mathrm{R}=\mathrm{CH}_{3}, \mathrm{CH}_{2} \mathrm{CH}_{3}$ & PLP-dependent aldolase & \\
\hline
\end{tabular}<smiles></smiles>

D-xylulose 5-phosphate<smiles>O=C(CO)CO</smiles>

dihydroxyacetone
Dihydroxyacetone synthase (DAS, EC

$$
\text { 2.2.1.3) }
$$

XuMP<smiles>C=O</smiles>

formaldehyde<smiles>O=C(CO)CO</smiles>

dihydroxyacetone
Formolase (FLS)

ThDP-dependent C-C Ligase
FLS

pathway<smiles>C=O</smiles>

formaldehyde<smiles>O=CCO</smiles>

glycolaldehyde
Glycolaldehyde synthase (GALS)

ThDP-dependent C-C Ligase
SACA

pathway<smiles>O=C[Se]O</smiles><smiles>O=C(CO)[Se]O</smiles>

formyl-CoA

2-hydroxyacyl CoA lyase (HACL) ThDP-dependent C-C Ligase

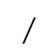

\subsection{Class I Aldolases for Formaldehyde Biotransformation}

Natural class I aldolases are generally promiscuous. It has been confirmed that several class I aldolases can tolerate formaldehyde as an acceptor substrate. From the perspective of biocatalysis, the promiscuity of class I aldolases provides solutions for producing valuable chemicals from formaldehyde. The following are examples of class I aldolases catalyzing formaldehyde as a receptor. 4-hydroxy-2-oxoglutarate aldolase (EC 4.1.3.16, class I aldolase) can catalyze the aldol addition of pyruvic acid or phenylpyruvic acid to formaldehyde [18]. DHAP-dependent aldolases, including D-Fructose-1, 6-bisphosphate (FBP) aldolases (FruA, EC 4.1.2.13), and tagatose 1, 6-diphosphate aldolase (TagA, EC 4.1.2.40), can catalyze the aldol addition of dihydroxyacetone phosphate (DHAP) to formaldehyde $[67,68]$. D-Fructose-6-phosphate aldolase (FSA, EC 4.1.2.n) can catalyze the aldol addition of dihydroxyacetone (DHA), hydroxyacetone (HA), and glycolaldehyde (GA) to formaldehyde [69].

\subsection{Class II Aldolases for Formaldehyde Biotransformation}

Hexulose phosphate synthase (HPS, EC 4.1.2.43) is a class II aldolase found in aerobic methylotrophic bacteria and is involved in the ribulose monophosphate (RuMP) cycle. It catalyzes D-ribulose 5-phosphate with formaldehyde to yield D-arabinose 3hexulose 6-phosphate. Due to strict substrate specificity, it is difficult to use hexulose phosphate synthase to synthesize value-added chiral products. While, by combining the non-oxidative glycolysis (NOG) with the RuMP, Igor W. Bogorad et al. constructed a methanol condensation cycle (MCC) [70], which can convert methanol to higher-chain alcohols or other acetyl-CoA derivatives using enzymatic reactions in a carbon-conserved 
and ATP-independent system (Figure 10). It is generally believed that the RuMP cycle is the most efficient naturally occurring route for methanol assimilation. However, realizing the heterogeneous construction of the RuMP cycle is a challenging task. Recently, a series of progress has been made [71,72]. By using metabolic robustness criteria followed by laboratory evolution, Frederic Y.-H. Chen et al. enabled the growth of the engineered E. coli with methanol as the sole carbon source [72].

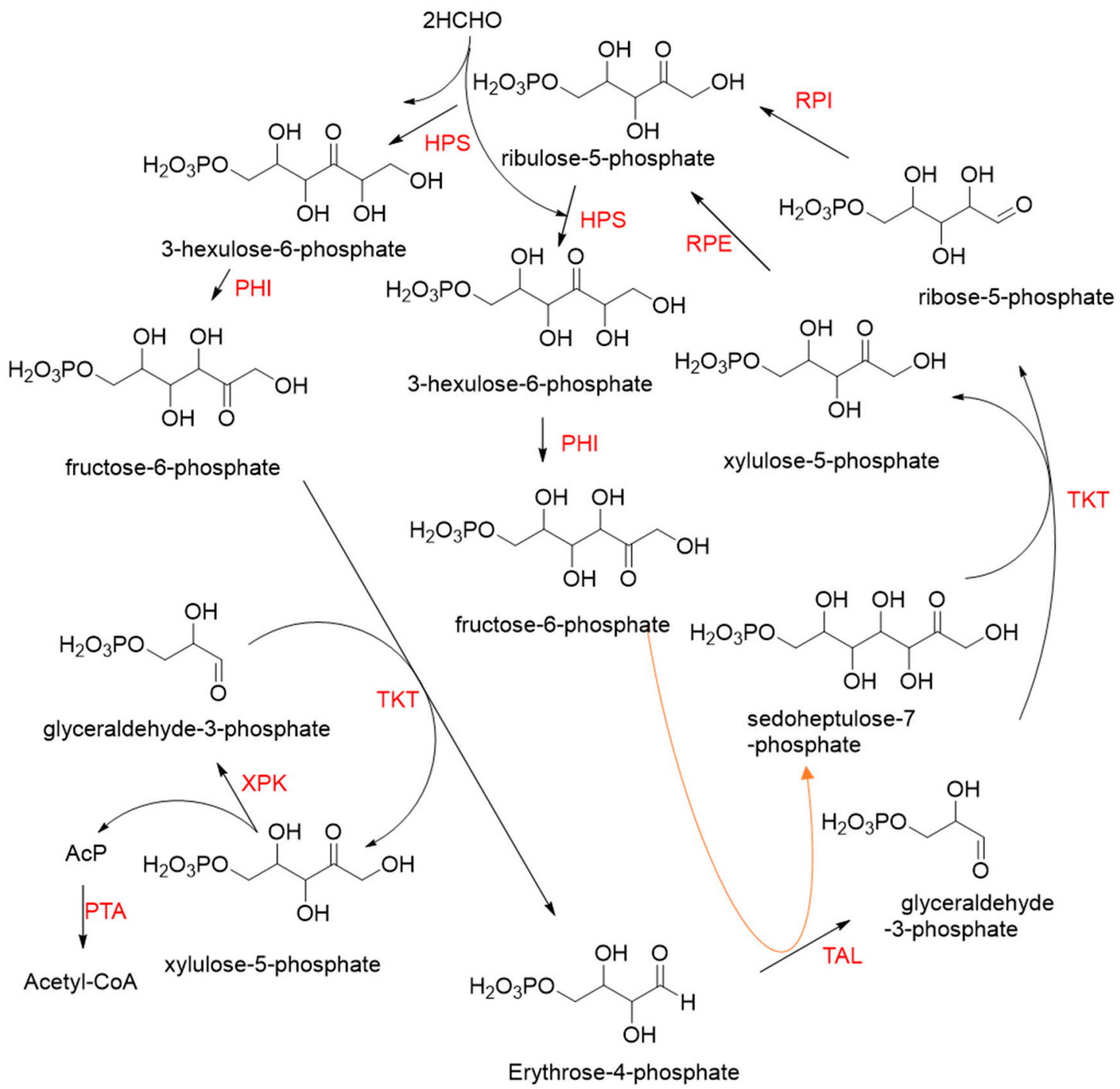

Figure 10. The methanol condensation cycle (MCC) [70]. HPS, hexulose phosphate synthase; PHI, phosphohexulose isomerase; TAL, transaldolase; TKT, transketolase; RPE, D-ribulose 5-phosphate epimerase; RPI, Ribose-5-phosphate isomerase; XPK, phosphoketolase; PTA, phosphate acetyltransferase.

Another class II aldolase, 2-keto-3-deoxy-L-rhamnonate aldolase (YfaU, EC 4.1.2.53), can also catalyze pyruvate with formaldehyde to generate 4-hydroxy-2-oxobutanoate. Combining YfaU with (S)-or (R)-selective transaminases, Karel Hernandez et al. achieved the stereoselective synthesis of (S)-and (R)-homoserine with high yield from formaldehyde and alanine [73]. Relying on the aldol reaction of pyruvate with formaldehyde as a superior synthetic pathway design, Hai He et al. constructed the homoserine cycle [74], which can assimilate two molecules of formaldehyde or methanol to generate one molecule of acetyl-CoA (Figure 11). Compared to the RuMP cycle, the homoserine cycle support higher theoretical yields of products that are derived from acetyl-CoA, including ethanol, acetone, butyrate, butanol, citrate, itaconate, 2-ketoglutarate, and levulinic acid. 


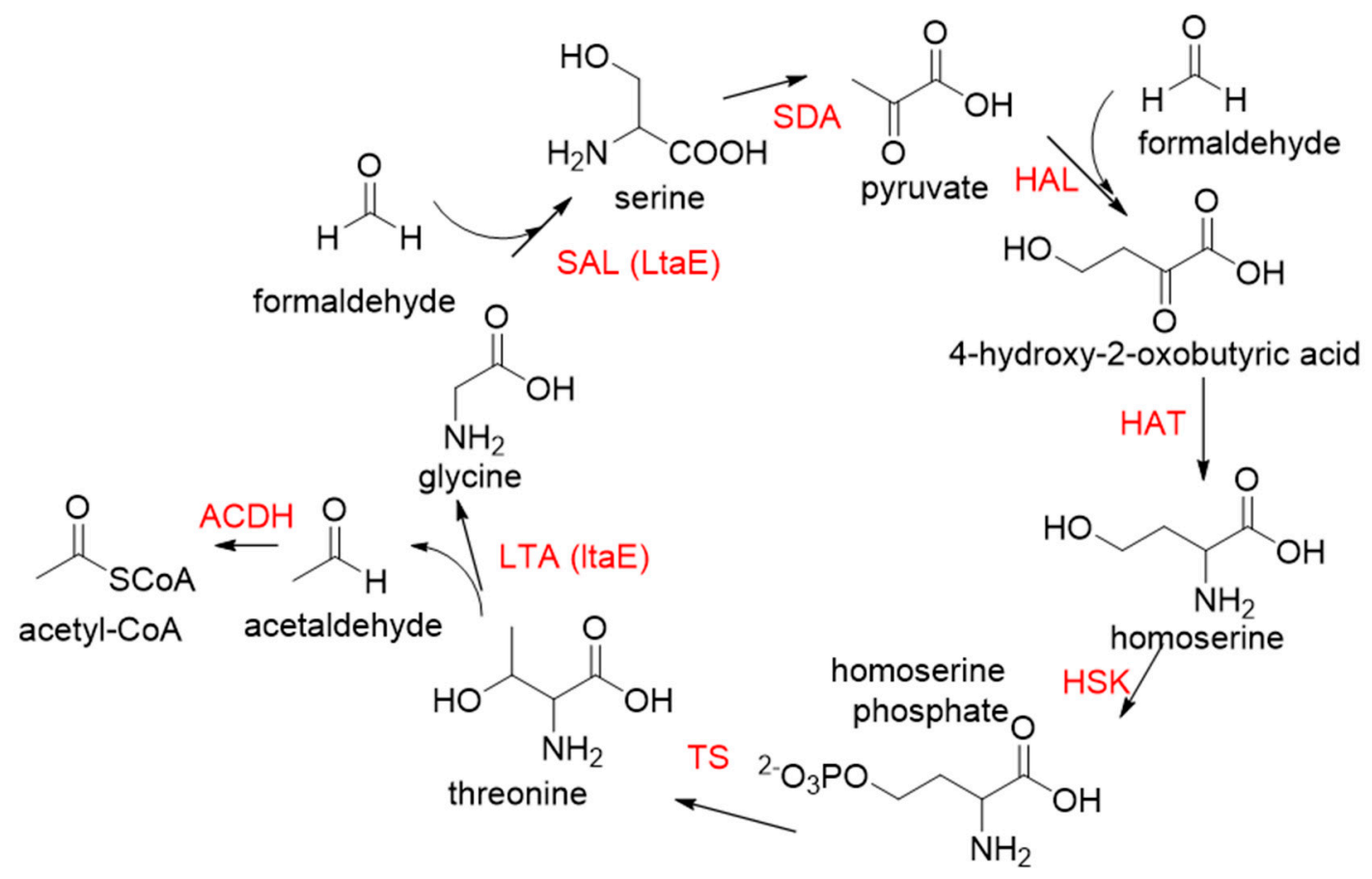

Figure 11. The homoserine cycle [74]. SAL, serine aldolase; SDA, serine deaminase; HAL, 4-hydroxy-2-oxobutanoate (HOB) aldolase; HAT, HOB aminotransferase; HSK, homoserine kinase; TS, threonine synthase; LTA, threonine aldolase; ACDH, acetylating acetaldehyde dehydrogenase. Both SAL and LTA are catalyzed by the same LtaE enzyme.

\subsection{PLP-Dependent Aldolases for Formaldehyde Biotransformation}

Serine hydroxymethyltransferase (SHMT, EC 2.1.2.1) belongs to the PLP-dependent aldolase family and is involved in serine cycle and reductive glycine pathway (RGP) $[75,76]$. The natural serine cycle pathway found in Methylobacterium extorquens AM1 can assimilate one molecule of formaldehyde or methanol and one molecule of bicarbonate into acetylCoA. Hong Yu et al. constructed a modified serine cycle [77], which uses formaldehyde dehydrogenase (Faldh) to simplify the oxidation of formaldehyde to formate, and also utilize the combination of alanine-glyoxylate transaminase and serine dehydratase to avoid hydroxypyruvate as an intermediate in the conversion from glyoxylate to PEP. By utilizing the modified serine cycle, they achieved the conversion of methanol to ethanol in an engineered E. coli strain.

Similar to SHMT, there are two types of PLP-dependent enzymes that can achieve the synthesis of unnatural amino acids. $\alpha$-methylserine hydroxymethyltransferase (MSHMT, EC 2.1.2.7) catalyzes the formation of $\alpha$-methyl-L-serine from D-alanine and formaldehyde [78]. $\alpha$-Methylserine aldolase can achieve the enantioselective formation of $\alpha$-methylL-serine and $\alpha$-ethyl-L-serine from D-alanine and D-butanine with formaldehyde [79]. Different from SHMT and MSHMT, $\alpha$-Methylserine aldolase is tetrahydrofolate (THF)independent in vitro.

\subsection{ThDP-Dependent C-C Ligases for Formaldehyde Biotransformation}

Dihydroxyacetone synthase (DAS, EC 2.2.1.3) belongs to the ThDP-dependent enzymes and is involved in xylulose monophosphate pathway (XuMP). It catalyzes Dxylulose 5-phosphate with formaldehyde to yield D-glyceraldehyde 3-phosphate and dihydroxyacetone [80]. The catalytic process can be described as follows: The activated ThDP (C2 of the ThDP is deprotonated) attack the carbonyl group of D-xylulose 5-phosphate, and then the bond between $C-2$ and $C-3$ of D-xylulose 5-phosphate break with the assistance of basic residues, generating 2- $\alpha, \beta$-dihydroxyethylidene-THDP (DHETHDP, enamine or carbanion intermediate). DHETHDP reacts with formaldehyde to gain dihydroxyacetone. Currently, DAS is not exploited as a biocatalyst. However, Pichia pastoris, a kind of 
methylotrophic yeast, have been engineered to produce chemicals from methanol using XuMP [81]. Similar to DAS, transketolase (TK, EC 2.2.1.1) can catalyze the reaction of Dfructose-6-phosphate or L-sorbose with formaldehyde to generate dihydroxyacetone [82].

The benzaldehyde lyase (BAL, EC 4.1.2.38) catalyzes the reversible ligation of two benzaldehyde to yield an (R)-benzoin [83]. When formaldehyde acts as a receptor, benzaldehyde first reacts with formaldehyde. However, wild-type BAL was shown to catalyze the oligomerization of formaldehyde into glycolaldehyde and dihydroxyacetone with low activity. Justin B. Siegel et al. engineered the BAL through computationally design and gained formolase (FLS) with high formaldehyde catalytic activity [22]. By combining FLS with acetyl-CoA synthase (ACS), acetaldehyde dehydrogenase (ACDH), and dihydroxyacetone kinase (DHAK), they created an FLS pathway, which assimilates formate into dihydroxyacetone phosphate with four steps (Figure 12A). Compared with the natural carbon fixation pathway, the FLS pathway has obvious advantages in chemical driving force, biomass yield, and reaction conditions (aerobic).

A

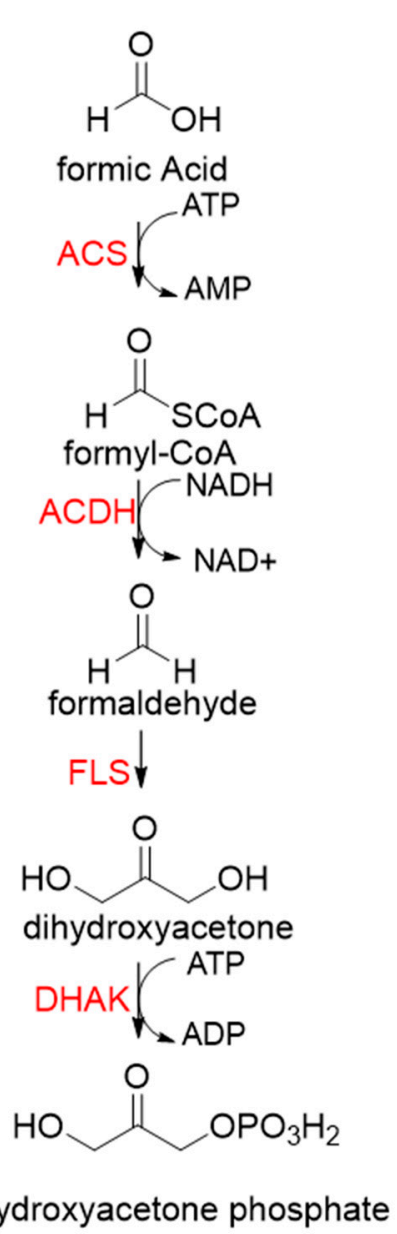

B

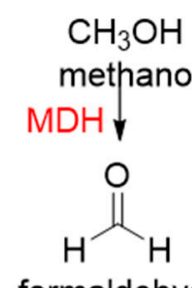

Figure 12. The formolase (FLS) pathway [22] and synthetic acetyl-CoA (SACA) pathway [23]. (A) The formolase (FLS) pathway. ACS, acetyl-CoA synthase; ACDH, acetaldehyde dehydrogenase; FLS, formolase; DHAK, dihydroxyacetone kinase. (B) The synthetic acetyl-CoA (SACA) pathway. GALS, glycolaldehyde synthase; ACPS, acetyl-phosphate synthase; PTA, phosphate acetyltransferase.

Benzoylformate decarboxylase (BFD, EC 4.1.1.7) is also a ThDP-dependent enzyme that catalyzes the conversion of benzoylformate to benzaldehyde and $\mathrm{CO}_{2}$ [84]. When formaldehyde is the only substrate, trace amounts of glycolaldehyde can be detected. Our research group engineered the BFD through directed evolution and gained glycolaldehyde synthase (GALS) with high catalytic activity for formaldehyde [23]. Different from FLS, GALS enables synthesis of glycolaldehyde even under high formaldehyde concentration 
conditions. By combining GALS with repurposed phosphoketolase (ACPS), and phosphate acetyltransferase (PTA), we constructed a synthetic acetyl-CoA (SACA) pathway, which assimilates formaldehyde into acetyl-CoA with only three steps (Figure 12B). Compared to the FLS pathway, SACA has obvious advantages in the synthesis of acetyl-CoA derivatives. When dihydroxyacetone phosphate (C3), the product of the FLS pathway, is converted to acetyl-CoA, one carbon is lost as $\mathrm{CO}_{2}$. Although both the FLS pathway and SACA pathway have shown great potential in assimilating $\mathrm{C} 1$ compounds, the low activity and affinity of FLS and GALS towards formaldehyde restrict their further application in vivo. Recently, Alexander Chou et al. reported that 2-hydroxyacyl CoA lyase (HACL) could catalyze the ligation of formyl-CoA with formaldehyde to produce glycolyl-CoA [85]. Compared to FLS and GALS, HACL shows higher catalytic activity and affinity towards formaldehyde. Although they mainly focus on the bioconversion of formaldehyde to glycolate, perhaps this alternative pathway will be available in vivo in the future.

\section{C-C Ligases for $\mathrm{CO}$ and Formate Biotransformation}

$\mathrm{CO}$ and formate are relatively inert compounds, and few enzymes can catalyze the C-C forming with them. However, they are ideal electron donors [86], which can be easily oxidized to $\mathrm{CO}_{2}$ and reduce power. The reducing power can support $\mathrm{CO}_{2}$ fixation and serves to provide the cell with energy. Several microbes can grow on formate or $\mathrm{CO}$ as the sole carbon source based on this strategy. $\mathrm{CO}$ is a toxic and flammable gas with low solubility, while formic acid is readily soluble and of low toxicity. So formic acid is a preferred carbon source and mediator of electrons.

\subsection{C-C Ligases for CO Biotransformation}

Diverse microbes can grow on $\mathrm{CO}$ as the sole carbon source, including anaerobes, such as Moorella thermoacetica, some purple sulfur bacteria akin to Rhodospirillum rubrum, and Carboxydothermus hydrogenoformans, as well as some aerobic carboxydobacteria like Oligotropha carboxidovorans [87]. For aerobes, $\mathrm{CO}$ is first oxidized to $\mathrm{CO}_{2}$ by $\mathrm{Mo}-\mathrm{Cu}-\mathrm{CODH}$ (CO dehydrogenase), and then $\mathrm{CO}_{2}$ is fixed by the $\mathrm{CBB}$ cycle. While for anaerobic microbes, $\mathrm{CO}$ is oxidized to $\mathrm{CO}_{2}$ by $\mathrm{Ni}-\mathrm{CODH}$, and the $\mathrm{CO}_{2}$ is then fixed by the WL pathway. Only $\mathrm{CO}$ dehydrogenase/acetyl-CoA-synthase complex existing in WL pathway can directly achieve the $\mathrm{C}-\mathrm{C}$ extension [88]. $\mathrm{CO}$ dehydrogenase (CODH) reversibly catalyzes $\mathrm{CO}_{2}$ reduction into $\mathrm{CO}$, and then acetyl-CoA synthase (ACS) catalyzes the condensation of in situ generated $\mathrm{CO}$ with $\mathrm{CoA}$ and a methyl group bound to the cobalt center in a $\mathrm{B}_{12}$ containing protein to generate acetyl-CoA. The WL pathway is not only a predominant $\mathrm{CO}_{2}$ sink under anaerobic conditions, but also used to synthesize desired products, such as ethanol and 2, 3-butanediol from industrial waste gases (mainly $\mathrm{CO}, \mathrm{CO}_{2}, \mathrm{H}_{2}$ ) [89]. In addition to chemical energy, several anaerobic bacteria, such as Sporomusa ovata, and Moorella thermoacetica, can employ light energy to enable the photosynthesis of acetic acid from $\mathrm{CO}_{2}$ [90-92].

\subsection{C-C Ligases for Formate Biotransformation}

Similar to CO assimilation, the CBB cycle and WL pathways are two carbon-fixation pathways known to support formatotrophic growth (i.e., growth on formate) by full oxidation of formate [93]. Different from $\mathrm{CO}$, formate can not only be oxidized to $\mathrm{CO}_{2}$ to achieve carbon fixation, but also can be reduced to methylene-THF in vivo. The serine pathway in methylotrophic organisms is also known to support formatotrophic growth [94,95]. The metheylene-THF can spontaneously release formaldehyde, so RuMP, XuMP, RGP, FLS, and SACA pathways are, thus, highly promising for supporting formatotrophic growth. Formate is a relatively strong acid $(\mathrm{pKa}=3.75)$, and normally it is deprotonated. So formate is a much poorer electrophile than $\mathrm{CO}_{2}$ [88]. The direct formate-fixing reactions are rare. Only one formate-fixing reaction catalyzed by pyruvate formate-lyase (PFL) is confirmed. This enzyme is mostly known to support pyruvate cleavage, producing an extra ATP molecule during anaerobic sugar fermentation. Now the reversibility of PFL has been demonstrated. 
Especially, the enzyme was shown to achieve the condensation of acetyl-CoA and formate in vivo [96], supporting efficient growth of E. coli on acetate and formate. The catalytic mechanism of PFL is a radical process, in which a single electron is extracted from formate by cysteine radical. The resulting formyl radical then attacks an enzyme-bound acetate moiety to generate a pyruvyl radical, which is released as pyruvate.

\section{Conclusions}

Newly mined or designed carboxylases and C-C ligases not only greatly expand the scope of $\mathrm{C} 1$ transformation in vitro, but also are expected to improve the efficiency of $\mathrm{C} 1$ assimilation in vivo. For example, mined prFMN-dependent (de)carboxylases enable efficient functionalization of terminal alkenes to the corresponding aldehyde, alcohol, amide, or amine derivatives through ambient $\mathrm{CO}_{2}$ fixation [65]. The reversible glycine cleavage system (GCS) enables the growth of E. coli on one-carbon compounds (formate and methanol) using the reductive glycine pathway, which is theoretically the most efficient route for formate assimilation to date [61]. With the development of synthetic biology, we believe that more and more carboxylases and $\mathrm{C}-\mathrm{C}$ ligases are being mined or designed.

Compared to $\mathrm{C} 1$ transformation in vitro, constructing an efficient $\mathrm{C} 1$ assimilation pathway is more desirable. Since an efficient $\mathrm{C} 1$ assimilation pathway will be possible to greatly reduce industrial production cost and also alleviate the pressure of resource supplement for bio-manufacturing in the future. It is encouraging that the constructed CETCH pathway based on crotonyl-CoA carboxylase/reductase, can use light energy to produce multi-carbon molecule glycolate from $\mathrm{CO}_{2}$, while also phosphorylating ADP to ATP. Although several artificial pathways, such as the homoserine cycle, formolase pathway (FLS), and synthetic acetyl-CoA (SACA) pathway, show great application potential, model strains (E. coli) that integrate these artificial pathways have low growth efficiency when C1 compounds is used as carbon source or energy source. Of course, a lot of work needs to be done to make these artificial pathways truly applied to industrial $\mathrm{C} 1$ biotransformation.

$\mathrm{C} 1$ compounds $\left(\mathrm{CO}_{2}, \mathrm{HCOOH}, \mathrm{HCHO}, \mathrm{CH}_{3} \mathrm{OH}\right.$, and $\left.\mathrm{CH}_{4}\right)$ can be interconverted. In methanotrophs, $\mathrm{CH}_{4}$ can be continuously oxidized to $\mathrm{CO}_{2}$ and then assimilated through the CBB cycle. In methanogens, $\mathrm{CO}_{2}$ can be continuously reduced to $\mathrm{CH}_{4}$ [97]. $\mathrm{CO}_{2}$ also can be continuously reduced to $\mathrm{CH}_{3} \mathrm{OH}$ in vitro [98]. Therefore, constructing a new assimilation pathway based on any of the $\mathrm{C} 1$ compounds can theoretically be used to assimilate other $\mathrm{C} 1$ compounds. However, among $\mathrm{C} 1$ compounds, only $\mathrm{CO}_{2}$ and formaldehyde are good candidate substrates for exploiting carboxylases and $\mathrm{C}-\mathrm{C}$ ligases. For the $\mathrm{CO}_{2}$ assimilation pathway, the energy source is an issue that must be considered. Both electric energy and light energy may be ideal energy sources. Recently, the semiconductor-bacteria biohybrid photosynthetic system was reported to efficiently realize the synthesis of acetic acid from $\mathrm{CO}_{2}$ with the non-photosynthetic bacteria [90]. Formaldehyde exhibits high and versatile reactivity, in comparison to other $\mathrm{C} 1$ compounds. However, formaldehyde is toxic to the cell, therefore, the mined or designed C-C ligases must have high activity and affinity towards formaldehyde.

Author Contributions: Q.Y. and X.G. reviewed related studies and wrote the first draft; H.J. and Y.L. reviewed and edited the manuscript. All authors have read and agreed to the published version of the manuscript.

Funding: This work was supported by the National Key R\&D Program of China (Grant No. 2018YFA0901600), Tianjin Synthetic Biotechnology Innovation Capacity Improvement Project (Grant No. TSBICIP-KJGG-007) and the Drug Innovation Major Project (2018ZX09711001-006-003).

Conflicts of Interest: The authors declare no conflict of interest.

\section{References}

1. OECD. The Bioeconomy to 2030: Designing a Policy Agenda; OECD: Paris, France, 2009; pp. 1-322.

2. Ducat, D.C.; Silver, P.A. Improving carbon fixation pathways. Curr. Opin. Chem. Biol. 2012, 16, 337-344. [CrossRef] 
3. Zhang, W.; Zhang, T.; Wu, S.; Wu, M.; Xin, F.; Dong, W.; Ma, J.; Zhang, M.; Jiang, M. Guidance for engineering of synthetic methylotrophy based on methanol metabolism in methylotrophy. RSC Adv. 2017, 7, 4083-4091. [CrossRef]

4. Yao, S.; Lyu, S.; An, Y.; Lu, J.; Gjermansen, C.; Schramm, A. Microalgae-bacteria symbiosis in microalgal growth and biofuel production: A review. J. Appl. Microbiol. 2019, 126, 359-368. [CrossRef]

5. Farrokh, P.; Sheikhpour, M.; Kasaeian, A.; Asadi, H.; Bavandi, R. Cyanobacteria as an eco-friendly resource for biofuel production: A critical review. Biotechnol. Prog. 2019, 35, e2835. [CrossRef]

6. Alishah Aratboni, H.; Rafiei, N.; Garcia-Granados, R.; Alemzadeh, A.; Morones-Ramírez, J.R. Biomass and lipid induction strategies in microalgae for biofuel production and other applications. Microb. Cell Fact. 2019, 18, 178. [CrossRef]

7. Ng, I.-S.; Tan, S.-I.; Kao, P.-H.; Chang, Y.-K.; Chang, J.-S. Recent Developments on Genetic Engineering of Microalgae for Biofuels and Bio-Based Chemicals. Biotechnol. J. 2017, 12, 1600644. [CrossRef] [PubMed]

8. Jain, S.; Prajapat, G.; Abrar, M.; Ledwani, L.; Singh, A.; Agrawal, A. Cyanobacteria as efficient producers of mycosporine-like amino acids. J. Basic Microbiol. 2017, 57, 715-727. [CrossRef] [PubMed]

9. Peña, D.A.; Gasser, B.; Zanghellini, J.; Steiger, M.G.; Mattanovich, D. Metabolic engineering of Pichia pastoris. Metab. Eng. 2018, 50, 2-15. [CrossRef]

10. Chistoserdova, L.; Kalyuzhnaya, M.G. Current Trends in Methylotrophy. Trends Microbiol. 2018, 26, 703-714. [CrossRef] [PubMed]

11. Bennett, R.K.; Steinberg, L.M.; Chen, W.; Papoutsakis, E.T. Engineering the bioconversion of methane and methanol to fuels and chemicals in native and synthetic methylotrophs. Curr. Opin. Biotechnol. 2018, 50, 81-93. [CrossRef]

12. Liu, Y.; Tu, X.; Xu, Q.; Bai, C.; Kong, C.; Liu, Q.; Yu, J.; Peng, Q.; Zhou, X.; Zhang, Y.; et al. Engineered monoculture and co-culture of methylotrophic yeast for de novo production of monacolin J and lovastatin from methanol. Metab. Eng. 2018, 45, 189-199. [CrossRef] [PubMed]

13. Cheah, W.Y.; Ling, T.C.; Juan, J.C.; Lee, D.-J.; Chang, J.-S.; Show, P.L. Biorefineries of carbon dioxide: From carbon capture and storage (CCS) to bioenergies production. Bioresour. Technol. 2016, 215, 346-356. [CrossRef]

14. Schlager, S.; Fuchsbauer, A.; Haberbauer, M.; Neugebauer, H.; Sariciftci, N.S. Carbon dioxide conversion to synthetic fuels using biocatalytic electrodes. J. Mater. Chem. A 2017, 5, 2429-2443. [CrossRef]

15. Singh, A.K.; Kishore, G.M.; Pakrasi, H.B. Emerging platforms for co-utilization of one-carbon substrates by photosynthetic organisms. Curr. Opin. Biotechnol. 2018, 53, 201-208. [CrossRef] [PubMed]

16. Hawkins, A.S.; McTernan, P.M.; Lian, H.; Kelly, R.M.; Adams, M.W.W. Biological conversion of carbon dioxide and hydrogen into liquid fuels and industrial chemicals. Curr. Opin. Biotechnol. 2013, 24, 376-384. [CrossRef] [PubMed]

17. Payer, S.E.; Faber, K.; Glueck, S.M. Non-Oxidative Enzymatic (De)Carboxylation of (Hetero)Aromatics and Acrylic Acid Derivatives. Adv. Synth. Catal. 2019, 361, 2402-2420. [CrossRef] [PubMed]

18. Desmons, S.; Fauré, R.; Bontemps, S. Formaldehyde as a Promising C1 Source: The Instrumental Role of Biocatalysis for Stereocontrolled Reactions. ACS Catal. 2019, 9, 9575-9588. [CrossRef]

19. Yu, H.; Li, X.; Duchoud, F.; Chuang, D.S.; Liao, J.C. Augmenting the Calvin-Benson-Bassham cycle by a synthetic malyl-CoAglycerate carbon fixation pathway. Nat. Commun. 2018, 9, 2008. [CrossRef] [PubMed]

20. Miller, T.; Beneyton, T.; Schwander, T.; Diehl, C.; Girault, M.; McLean, R.; Chotel, T.; Claus, P.; Cortina, N.; Baret, J.-C.; et al. Light-powered CO 2 fixation in a chloroplast mimic with natural and synthetic parts. Science 2020, 368, 649-654. [CrossRef] [PubMed]

21. Schwander, T.; Schada von Borzyskowski, L.; Burgener, S.; Cortina, N.S.; Erb, T.J. A synthetic pathway for the fixation of carbon dioxide in vitro. Science 2016, 354, 900-904. [CrossRef]

22. Siegel, J.B.; Smith, A.L.; Poust, S.; Wargacki, A.J.; Bar-Even, A.; Louw, C.; Shen, B.W.; Eiben, C.B.; Tran, H.M.; Noor, E.; et al. Computational protein design enables a novel one-carbon assimilation pathway. Proc. Natl. Acad. Sci. USA 2015, 112, 3704-3709. [CrossRef] [PubMed]

23. Lu, X.; Liu, Y.; Yang, Y.; Wang, S.; Wang, Q.; Wang, X.; Yan, Z.; Cheng, J.; Liu, C.; Yang, X.; et al. Constructing a synthetic pathway for acetyl-coenzyme A from one-carbon through enzyme design. Nat. Commun. 2019, 10, 1378. [CrossRef]

24. Glueck, S.M.; Gümüs, S.; Fabian, W.M.F.; Faber, K. Biocatalytic carboxylation. Chem. Soc. Rev. 2010, 39, 313-328. [CrossRef]

25. Hartman, F.C.; Harpel, M.R. Structure, Function, Regulation, and Assembly of D-Ribulose-1,5-Bisphosphate Carboxylase/Oxygenase. Annu. Rev. Biochem. 1994, 63, 197-232. [CrossRef]

26. Schneider, G.; Lindqvist, Y.; Branden, C.I. Rubisco: Structure and Mechanism. Annu. Rev. Biophys. Biomol. Struct. 1992, 21, 119-143. [CrossRef] [PubMed]

27. Andersson, I. Catalysis and regulation in Rubisco. J. Exp. Bot. 2008, 59, 1555-1568. [CrossRef] [PubMed]

28. Stec, B. Structural mechanism of RuBisCO activation by carbamylation of the active site lysine. Proc. Natl. Acad. Sci. USA 2012, 109, 18785-18790. [CrossRef]

29. Antonovsky, N.; Gleizer, S.; Noor, E.; Zohar, Y.; Herz, E.; Barenholz, U.; Zelcbuch, L.; Amram, S.; Wides, A.; Tepper, N.; et al. Sugar Synthesis from $\mathrm{CO}_{2}$ in Escherichia coli. Cell 2016, 166, 115-125. [CrossRef]

30. Gleizer, S.; Ben-Nissan, R.; Bar-On, Y.M.; Antonovsky, N.; Noor, E.; Zohar, Y.; Jona, G.; Krieger, E.; Shamshoum, M.; Bar-Even, A.; et al. Conversion of Escherichia coli to Generate All Biomass Carbon from $\mathrm{CO}_{2}$. Cell 2019, 179, 1255-1263. [CrossRef] [PubMed]

31. Gassler, T.; Sauer, M.; Gasser, B.; Egermeier, M.; Troyer, C.; Causon, T.; Hann, S.; Mattanovich, D.; Steiger, M.G. The industrial yeast Pichia pastoris is converted from a heterotroph into an autotroph capable of growth on $\mathrm{CO}_{2}$. Nat. Biotechnol. 2020, 38, 210-216. [CrossRef] [PubMed] 
32. Tong, L. Structure and function of biotin-dependent carboxylases. Cell Mol. Life Sci. 2013, 70, 863-891. [CrossRef] [PubMed]

33. Sarawut, J.; John, C.W. The Biotin Enzyme Family: Conserved Structural Motifs and Domain Rearrangements. Curr. Protein Pept. Sci. 2003, 4, 217-229.

34. St. Maurice, M.; Reinhardt, L.; Surinya, K.H.; Attwood, P.V.; Wallace, J.C.; Cleland, W.W.; Rayment, I. Domain architecture of pyruvate carboxylase, a biotin-dependent multifunctional enzyme. Science 2007, 317, 1076-1079. [CrossRef] [PubMed]

35. Huang, C.S.; Sadre-Bazzaz, K.; Shen, Y.; Deng, B.; Zhou, Z.H.; Tong, L. Crystal structure of the $\alpha_{6} \beta_{6}$ holoenzyme of propionylcoenzyme A carboxylase. Nature 2010, 466, 1001-1005. [CrossRef] [PubMed]

36. Tong, L. Acetyl-coenzyme A carboxylase: Crucial metabolic enzyme and attractive target for drug discovery. Cell. Mol. life Sci. CMLS 2005, 62, 1784-1803. [CrossRef]

37. Wongkittichote, P.; Ah Mew, N.; Chapman, K.A. Propionyl-CoA carboxylase-A review. Mol. Genet. Metab. 2017, 122, 145-152. [CrossRef] [PubMed]

38. Heider, J.; Schuhle, K.; Frey, J.; Schink, B. Activation of Acetone and Other Simple Ketones in Anaerobic Bacteria. J. Mol. Microbiol. Biotechnol. 2016, 26, 152-164. [CrossRef]

39. Boyd, J.M.; Ensign, S.A. ATP-Dependent Enolization of Acetone by Acetone Carboxylase from Rhodobacter capsulatus. Biochemistry 2005, 44, 8543-8553. [CrossRef]

40. Weidenweber, S.; Schühle, K.; Demmer, U.; Warkentin, E.; Ermler, U.; Heider, J. Structure of the acetophenone carboxylase core complex: Prototype of a new class of ATP-dependent carboxylases/hydrolases. Sci. Rep. 2017, 7, 39674. [CrossRef]

41. Mai, X.; Adams, M.W. Characterization of a fourth type of 2-keto acid-oxidizing enzyme from a hyperthermophilic archaeon: 2-ketoglutarate ferredoxin oxidoreductase from Thermococcus litoralis. J. Bacteriol. 1996, 178, 5890-5896. [CrossRef] [PubMed]

42. Menon, A.L.; Hendrix, H.; Hutchins, A.; Verhagen, M.F.J.M.; Adams, M.W.W. The $\delta$-Subunit of Pyruvate Ferredoxin Oxidoreductase from Pyrococcus furiosus Is a Redox-Active, Iron-Sulfur Protein: Evidence for an Ancestral Relationship with 8Fe-Type Ferredoxins. Biochemistry 1998, 37, 12838-12846. [CrossRef]

43. Ragsdale, S.W. Pyruvate Ferredoxin Oxidoreductase and Its Radical Intermediate. Chem. Rev. 2003, 103, 2333-2346. [CrossRef]

44. Soundar, S.; O'Hagan, M.; Fomulu, K.S.; Colman, R.F. Identification of Mn2+-binding Aspartates from $\alpha, \beta$, and $\gamma$ Subunits of Human NAD-dependent Isocitrate Dehydrogenase. J. Biol. Chem. 2006, 281, 21073-21081. [CrossRef]

45. Erb, T.J.; Berg, I.A.; Brecht, V.; Müller, M.; Fuchs, G.; Alber, B.E. Synthesis of C5-dicarboxylic acids from C2-units involving crotonyl-CoA carboxylase/reductase: The ethylmalonyl-CoA pathway. Proc. Natl. Acad. Sci. USA 2007, 104, 10631. [CrossRef]

46. Stoffel, G.M.M.; Saez, D.A.; DeMirci, H.; Vögeli, B.; Rao, Y.; Zarzycki, J.; Yoshikuni, Y.; Wakatsuki, S.; Vöhringer-Martinez, E.; Erb, T.J. Four amino acids define the CO 2 binding pocket of enoyl-CoA carboxylases/reductases. Proc. Natl. Acad. Sci. USA 2019, 116, 13964. [CrossRef] [PubMed]

47. Bernhardsgrutter, I.; Schell, K.; Peter, D.M.; Borjian, F.; Saez, D.A.; Vohringer-Martinez, E.; Erb, T.J. Awakening the Sleeping Carboxylase Function of Enzymes: Engineering the Natural $\mathrm{CO}_{2}$-Binding Potential of Reductases. J. Am. Chem. Soc. 2019, 141, 9778-9782. [CrossRef] [PubMed]

48. Erb, T.J.; Brecht, V.; Fuchs, G.; Müller, M.; Alber, B.E. Carboxylation mechanism and stereochemistry of crotonyl-CoA carboxylase/reductase, a carboxylating enoyl-thioester reductase. Proc. Natl. Acad. Sci. USA 2009, 106, 8871. [CrossRef] [PubMed]

49. Peter, D.M.; Schada von Borzyskowski, L.; Kiefer, P.; Christen, P.; Vorholt, J.A.; Erb, T.J. Screening and Engineering the Synthetic Potential of Carboxylating Reductases from Central Metabolism and Polyketide Biosynthesis. Angew. Chem. 2015, 54, 13457-13461. [CrossRef]

50. Kai, Y.; Matsumura, H.; Izui, K. Phosphoenolpyruvate carboxylase: Three-dimensional structure and molecular mechanisms. Arch. Biochem. Biophys. 2003, 414, 170-179. [CrossRef]

51. Hatch, M.D. C4 photosynthesis: A unique elend of modified biochemistry, anatomy and ultrastructure. Biochim. Biophys. Acta Rev. Bioenerg. 1987, 895, 81-106. [CrossRef]

52. Chollet, R.; Vidal, J.; O'Leary, M.H. PHOSPHOENOLPYRUVATE CARBOXYLASE: A Ubiquitous, Highly Regulated Enzyme in Plants. Annu. Rev. Plant Physiol. Plant Mol. Biol. 1996, 47, 273-298. [CrossRef]

53. Cotton, C.A.; Edlich-Muth, C.; Bar-Even, A. Reinforcing carbon fixation: $\mathrm{CO}_{2}$ reduction replacing and supporting carboxylation. Curr. Opin. Biotechnol. 2018, 49, 49-56. [CrossRef]

54. Kutter, S.; Wille, G.; Relle, S.; Weiss, M.S.; Hubner, G.; Konig, S. The crystal structure of pyruvate decarboxylase from Kluyveromyces lactis. Implications for the substrate activation mechanism of this enzyme. FEBS J. 2006, 273, 4199-4209. [CrossRef]

55. Miyazaki, M.; Shibue, M.; Ogino, K.; Nakamura, H.; Maeda, H. Enzymatic synthesis of pyruvic acid from acetaldehyde and carbon dioxide. Chem. Commun. 2001, 18, 1800-1801. [CrossRef]

56. Martin, J.; Eisoldt, L.; Skerra, A. Fixation of gaseous $\mathrm{CO}_{2}$ by reversing a decarboxylase for the biocatalytic synthesis of the essential amino acid l-methionine. Nat. Catal. 2018, 1, 555-561. [CrossRef]

57. Gonzales, J.N.; Matson, M.M.; Atsumi, S. Nonphotosynthetic Biological $\mathrm{CO}_{2}$ Reduction. Biochemistry 2019, 58, 1470-1477. [CrossRef] [PubMed]

58. Tashiro, Y.; Hirano, S.; Matson, M.M.; Atsumi, S.; Kondo, A. Electrical-biological hybrid system for $\mathrm{CO}_{2}$ reduction. Metab. Eng. 2018, 47, 211-218. [CrossRef]

59. Yishai, O.; Bouzon, M.; Doring, V.; Bar-Even, A. In Vivo Assimilation of One-Carbon via a Synthetic Reductive Glycine Pathway in Escherichia coli. ACS Synth. Biol. 2018, 7, 2023-2028. [CrossRef] [PubMed] 
60. Gonzalez de la Cruz, J.; Machens, F.; Messerschmidt, K.; Bar-Even, A. Core Catalysis of the Reductive Glycine Pathway Demonstrated in Yeast. ACS Synth. Biol. 2019, 8, 911-917. [CrossRef] [PubMed]

61. Kim, S.; Lindner, S.N.; Aslan, S.; Yishai, O.; Wenk, S.; Schann, K.; Bar-Even, A. Growth of E. coli on formate and methanol via the reductive glycine pathway. Nat. Chem. Biol. 2020, 16, 538-545. [CrossRef] [PubMed]

62. Sánchez-Andrea, I.; Guedes, I.A.; Hornung, B.; Boeren, S.; Lawson, C.E.; Sousa, D.Z.; Bar-Even, A.; Claassens, N.J.; Stams, A.J.M. The reductive glycine pathway allows autotrophic growth of Desulfovibrio desulfuricans. Nat. Commun. 2020, 11, 5090. [CrossRef] [PubMed]

63. Payne, K.A.; White, M.D.; Fisher, K.; Khara, B.; Bailey, S.S.; Parker, D.; Rattray, N.J.; Trivedi, D.K.; Goodacre, R.; Beveridge, R.; et al. New cofactor supports $\alpha, \beta$-unsaturated acid decarboxylation via 1,3-dipolar cycloaddition. Nature 2015, 522, 497-501. [CrossRef] [PubMed]

64. White, M.D.; Payne, K.A.; Fisher, K.; Marshall, S.A.; Parker, D.; Rattray, N.J.; Trivedi, D.K.; Goodacre, R.; Rigby, S.E.; Scrutton, N.S.; et al. UbiX is a flavin prenyltransferase required for bacterial ubiquinone biosynthesis. Nature 2015, 522, 502-506. [CrossRef]

65. Aleku, G.A.; Saaret, A.; Bradshaw-Allen, R.T.; Derrington, S.R.; Titchiner, G.R.; Gostimskaya, I.; Gahloth, D.; Parker, D.A.; Hay, S.; Leys, D. Enzymatic C-H activation of aromatic compounds through $\mathrm{CO}_{2}$ fixation. Nat. Chem. Biol. 2020, 16, 1255-1260. [CrossRef]

66. Kalyuzhnaya, M.G.; Puri, A.W.; Lidstrom, M.E. Metabolic engineering in methanotrophic bacteria. Metab. Eng. 2015, 29, 142-152. [CrossRef]

67. Bednarski, M.D.; Simon, E.S.; Bischofberger, N.; Fessner, W.D.; Kim, M.J.; Lees, W.; Saito, T.; Waldmann, H.; Whitesides, G.M. Rabbit muscle aldolase as a catalyst in organic synthesis. J. Am. Chem. Soc. 1989, 111, 627-635. [CrossRef]

68. Yang, J.; Li, J.; Men, Y.; Zhu, Y.; Zhang, Y.; Sun, Y.; Ma, Y. Biosynthesis of 1-Sorbose and 1-Psicose Based on C-C Bond Formation Catalyzed by Aldolases in an Engineered Corynebacterium glutamicum Strain. Appl. Environ. Microbiol. 2015, 81, 4284-4294. [CrossRef] [PubMed]

69. Garrabou, X.; Castillo, J.A.; Guérard-Hélaine, C.; Parella, T.; Joglar, J.; Lemaire, M.; Clapés, P. Asymmetric Self- and Cross-Aldol Reactions of Glycolaldehyde Catalyzed by D-Fructose-6-phosphate Aldolase. Angew. Chem. 2009, 48, 5521-5525. [CrossRef] [PubMed]

70. Bogorad, I.W.; Chen, C.-T.; Theisen, M.K.; Wu, T.-Y.; Schlenz, A.R.; Lam, A.T.; Liao, J.C. Building carbon-carbon bonds using a biocatalytic methanol condensation cycle. Proc. Natl. Acad. Sci. USA 2014, 111, 15928. [CrossRef]

71. Meyer, F.; Keller, P.; Hartl, J.; Groninger, O.G.; Kiefer, P.; Vorholt, J.A. Methanol-essential growth of Escherichia coli. Nat Commun. 2018, 9, 1508. [CrossRef]

72. Chen, F.Y.; Jung, H.W.; Tsuei, C.Y.; Liao, J.C. Converting Escherichia coli to a Synthetic Methylotroph Growing Solely on Methanol. Cell 2020, 182, 933-946. [CrossRef]

73. Hernandez, K.; Bujons, J.; Joglar, J.; Charnock, S.J.; Domínguez de María, P.; Fessner, W.D.; Clapés, P. Combining Aldolases and Transaminases for the Synthesis of 2-Amino-4-hydroxybutanoic Acid. ACS Catal. 2017, 7, 1707-1711. [CrossRef]

74. He, H.; Hoper, R.; Dodenhoft, M.; Marliere, P.; Bar-Even, A. An optimized methanol assimilation pathway relying on promiscuous formaldehyde-condensing aldolases in E. coli. Metab. Eng. 2020, 60, 1-13. [CrossRef] [PubMed]

75. Šmejkalová, H.; Erb, T.J.; Fuchs, G. Methanol Assimilation in Methylobacterium extorquens AM1: Demonstration of All Enzymes and Their Regulation. PLoS ONE 2010, 5, e13001. [CrossRef] [PubMed]

76. Alexander, F.W.; Sandmeier, E.; Mehta, P.K.; Christen, P. Evolutionary relationships among pyridoxal-5'-phosphate-dependent enzymes. Eur. J. Biochem. 1994, 219, 953-960. [CrossRef]

77. Yu, H.; Liao, J.C. A modified serine cycle in Escherichia coli coverts methanol and $\mathrm{CO}_{2}$ to two-carbon compounds. Nat. Commun. 2018, 9, 3992. [CrossRef] [PubMed]

78. Nozaki, H.; Kuroda, S.; Watanabe, K.; Yokozeki, K. Screening of microorganisms producing $\alpha$-methylserine hydroxymethyltransferase, purification of the enzyme, gene cloning, and application to the enzymatic synthesis of $\alpha$-methyl-1-serine. J. Mol. Catal. $B$ Enzym. 2009, 56, 221-226. [CrossRef]

79. Nozaki, H.; Kuroda, S.; Watanabe, K.; Yokozeki, K. Gene Cloning of $\alpha$-Methylserine Aldolase from Variovorax paradoxus and Purification and Characterization of the Recombinant Enzyme. Biosci. Biotechnol. Biochem. 2008, 72, 2580-2588. [CrossRef] [PubMed]

80. Ro, Y.T.; Eom, C.Y.; Song, T.; Cho, J.W.; Kim, Y.M. Dihydroxyacetone synthase from a methanol-utilizing carboxydobacterium, Acinetobacter sp. strain JC1 DSM 3803. J. Bacteriol. 1997, 179, 6041. [CrossRef]

81. Guo, F.; Dai, Z.; Peng, W.; Zhang, S.; Zhou, J.; Ma, J.; Dong, W.; Xin, F.; Zhang, W.; Jiang, M. Metabolic engineering of Pichia pastoris for malic acid production from methanol. Biotechnol. Bioeng. 2020, 118, 1-15. [CrossRef]

82. Kato, N.; Higuchi, T.; Sakazawa, C.; Nishizawa, T.; Tani, Y.; Yamada, H. Purification and properties of a transketolase responsible for formaldehyde fixation in a methanol-utilizing yeast, candida boidinii (Kloeckera sp.) No. 2201. Biochim. Biophys. Acta 1982, 715, 143-150. [PubMed]

83. Chakraborty, S.; Nemeria, N.; Yep, A.; McLeish, M.; Kenyon, G.; Jordan, F. Mechanism of Benzaldehyde Lyase Studied via Thiamin Diphosphate-Bound Intermediates and Kinetic Isotope Effects. Biochemistry 2008, 47, 3800-3809. [CrossRef] [PubMed]

84. Hasson, M.S.; Muscate, A.; McLeish, M.J.; Polovnikova, L.S.; Gerlt, J.A.; Kenyon, G.L.; Petsko, G.A.; Ringe, D. The crystal structure of benzoylformate decarboxylase at 1.6 A resolution: Diversity of catalytic residues in thiamin diphosphate-dependent enzymes. Biochemistry 1998, 37, 9918-9930. [CrossRef] [PubMed] 
85. Chou, A.; Clomburg, J.M.; Qian, S.; Gonzalez, R. 2-Hydroxyacyl-CoA lyase catalyzes acyloin condensation for one-carbon bioconversion. Nat. Chem. Biol. 2019, 15, 900-906. [CrossRef] [PubMed]

86. Flamholz, A.; Noor, E.; Bar-Even, A.; Milo, R. eQuilibrator-The biochemical thermodynamics calculator. Nucleic Acids Res. 2011, 40, D770-D775. [CrossRef]

87. Can, M.; Armstrong, F.A.; Ragsdale, S.W. Structure, function, and mechanism of the nickel metalloenzymes, CO dehydrogenase, and acetyl-CoA synthase. Chem. Rev. 2014, 114, 4149-4174. [CrossRef]

88. Bar-Even, A. Formate Assimilation: The Metabolic Architecture of Natural and Synthetic Pathways. Biochemistry 2016, 55, 3851-3863. [CrossRef]

89. Li, X.; Griffin, D.; Li, X.; Henson, M.A. Incorporating hydrodynamics into spatiotemporal metabolic models of bubble column gas fermentation. Biotechnol. Bioeng. 2019, 116, 28-40. [CrossRef]

90. Gai, P.; Yu, W.; Zhao, H.; Qi, R.; Li, F.; Liu, L.; Lv, F.; Wang, S. Solar-Powered Organic Semiconductor-Bacteria Biohybrids for CO 2 Reduction into Acetic Acid. Angew. Chem. 2020, 59, 7224-7229. [CrossRef]

91. Sakimoto, K.; Wong, A.; Yang, P. Self-photosensitization of nonphotosynthetic bacteria for solar-to-chemical production. Science 2016, 351, 74-77. [CrossRef]

92. Liu, C.; Gallagher, J.J.; Sakimoto, K.K.; Nichols, E.M.; Chang, C.J.; Chang, M.C.Y.; Yang, P. Nanowire-Bacteria Hybrids for Unassisted Solar Carbon Dioxide Fixation to Value-Added Chemicals. Nano Lett. 2015, 15, 3634-3639. [CrossRef] [PubMed]

93. Bar-Even, A.; Noor, E.; Flamholz, A.; Milo, R. Design and analysis of metabolic pathways supporting formatotrophic growth for electricity-dependent cultivation of microbes. Biochim. Biophys. Acta Bioenerg. 2013, 1827, 1039-1047. [CrossRef] [PubMed]

94. Schrader, J.; Schilling, M.; Holtmann, D.; Sell, D.; Filho, M.V.; Marx, A.; Vorholt, J.A. Methanol-based industrial biotechnology: Current status and future perspectives of methylotrophic bacteria. Trends Biotechnol. 2009, 27, 107-115. [CrossRef]

95. Chistoserdova, L.; Kalyuzhnaya, M.G.; Lidstrom, M.E. The Expanding World of Methylotrophic Metabolism. Annu. Rev. Microbiol. 2009, 63, 477-499. [CrossRef] [PubMed]

96. Zelcbuch, L.; Lindner, S.N.; Zegman, Y.; Vainberg Slutskin, I.; Antonovsky, N.; Gleizer, S.; Milo, R.; Bar-Even, A. Pyruvate Formate-Lyase Enables Efficient Growth of Escherichia coli on Acetate and Formate. Biochemistry 2016, 55, 2423-2426. [CrossRef] [PubMed]

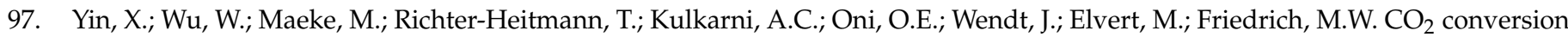
to methane and biomass in obligate methylotrophic methanogens in marine sediments. ISME J. 2019, 13, 2107-2119. [CrossRef]

98. Singh, R.K.; Singh, R.; Sivakumar, D.; Kondaveeti, S.; Kim, T.; Li, J.; Sung, B.H.; Cho, B.-K.; Kim, D.R.; Kim, S.C.; et al. Insights into Cell-Free Conversion of $\mathrm{CO}_{2}$ to Chemicals by a Multienzyme Cascade Reaction. ACS Catal. 2018, 8, 11085-11093. [CrossRef] 